\title{
The Emerging Role of Topical Ocular Drugs to Target the Posterior Eye
}

\author{
Lixiang Wang $\cdot$ Mikael Ben Zhou $\cdot$ Hui Zhang
}

Received: May 18, 2021 / Accepted: June 16, 2021 / Published online: July 4, 2021

(c) The Author(s) 2021

\section{ABSTRACT}

The prevalence of chronic fundus diseases is increasing with the aging of the general population. The treatment of these intraocular diseases relies on invasive drug delivery because of the globular structure and multiple barriers of the eye. Frequent intraocular injections bring heavy burdens to the medical care system and patients. The use of topical drugs to treat retinal diseases has always been an attractive solution. The fast development of new materials and technologies brings the possibility to develop innovative topical formulations. This article reviews anatomical and physiological barriers of the eye which affect the bioavailability of topical drugs. In addition, we summarize innovative topical formulations which enhance the permeability of drugs through the ocular surface

L. Wang

Department of Ophthalmology, West China

Hospital, Sichuan University, Chengdu, China

M. B. Zhou

Medical Faculty, Lund University, Lund, Sweden

H. Zhang

Yuanpu Eye Biopharmaceutical Co. Ltd., Chengdu, China

H. Zhang $(\bowtie)$

No. 14 Jiuxing Avenue, Gaoxin District, Chengdu, China

e-mail: zhanghui@bio-eyepro.com and/or extend the drug retention time in the eye. This article also reviews the differences of eyes between different laboratory animals to address the translational challenges of preclinical models. The fast development of in vitro eye models may provide more tools to increase the clinical translationality of topical formulations for intraocular diseases. Clinical successes of topical formulations rely on continuous and collaborative efforts between different disciplines.

Keywords: Comparative anatomy of the eye; Ocular fundus diseases; In vitro eye model; Nanoparticles; Ocular barriers; Ocular drug delivery; Topical formulation; In vivo eye models 


\section{Key Summary Points}

Increasing life expectancy is accompanied by more age-related and chronic posterior eye diseases, which require long-term intervention.

Topical eye drugs must overcome various cellular and liquid barriers to effectively enter the retina from the ocular surface.

Novel topical drugs with innovative formulations have shown encouraging results in improving their permeability and retention time. These formulations include nanospheres, nanocapsules, nanomicelles, nanovesicles, dendrimers, in situ gels, and microneedles.

The rapid and successful clinical translation of novel topical drugs relies on a thorough understanding of the significance and limitations of preclinical models. The emerging in vitro models may provide some valuable information beyond animal models.

\section{DIGITAL FEATURES}

This article is published with digital features, including a summary slide, to facilitate understanding of the article. To view digital features for this article go to https://doi.org/10.6084/ m9.figshare.14791566.

\section{INTRODUCTION}

With the improvement of the quality of life and average life expectancy, ophthalmologists are facing more challenging diseases caused by internal factors, such as age-related degenerative diseases, metabolic diseases, and systemic immune diseases [1]. Current effective drugs for intraocular diseases largely require invasive drug delivery. Frequent intraocular operations bring heavy burdens on the medical care system and increase the risk of intraocular hemorrhage or infection $[2,3]$. Patients may also be discouraged by the frequent treatment regimen and have compromised compliance for the long-term therapy [4]. Thus, the development of less invasive ocular formulations has become a great need for patients with chronic and vision-threatening fundus diseases. Moreover, more drugs with neuroprotection functions may have beneficial effects on ocular disorders if they can be effectively delivered to the fundus [5].

Topical drugs, which are the most widely applied ocular formulations, have been recently explored as possible tools for the treatment of fundus diseases [6]. However, as a result of the structural and physiological barriers of the eyeball, this convenient drug administration method generally can not effectively deliver drug molecules to the back of the eye. There have been extensive explorations to enhance the delivery efficiency of topical formulations [7-9]. Currently, only a few topical formulations to target the posterior segment are in clinical development, including a dexamethasone in cyclodextrin microparticle formulation for the treatment of diabetic macular edema (DME) (phase II/III) [10], difluprednate emulsion for the treatment of DME (off-label use) [11], Aganirsen emulsion for the treatment of ischemic central retinal vein occlusion (phase II/III) [12], and OCS-01 in a soluble nanoparticle formulation for the treatment of DME (phase III) [13, 14]. However, in recent years, the emerging science of new materials has brought possibilities for generating many novel topical drug formulations, which receive increasing attention in preclinical studies.

This review summarizes the features of ocular barriers that prevent topical drugs from entering and staying in the eye and the innovative approaches that overcome these barriers to deliver drug molecules to intraocular targets. In addition, some key parameters of laboratory animal and human eyes are reviewed, as they are factors that can influence the preclinical to clinical translation of novel formulations. The purpose of this article is to share ophthalmology knowledge, promote multidisciplinary cooperation, accelerate the clinical translation 
of noninvasive ocular drug delivery, and ultimately bring benefits to patients with chronic fundus diseases.

\section{OCULAR BARRIERS THAT LIMIT THE BIOAVAILABILITY OF TOPICAL DRUGS}

Drugs applied topically to the ocular surface can theoretically reach the intraocular tissues via three pathways: (1) penetrate through the cornea, aqueous humor, and vitreous body; (2) penetrate through conjunctiva and sclera to reach the choroid, and then reach the aqueous, vitreous, or retina; (3) enter the systemic circulation and reach the retina via retinal vasculatures. The first two routes play dominant roles in the intraocular distribution of topical drugs $[15,16]$. In reality, however, most of the drug molecules cannot effectively reach the fundus through these routes. Multiple static and dynamic barriers restrict the penetration and retention of drugs (Fig. 1).

\section{Running Tear Film Constantly Washes Away Drugs from the Ocular Surface}

The front surface of the eye is the tear film. This liquid surface looks like a slow-moving "waterfall", which continuously moves downwards, and drains into the nasolacrimal duct and the nasal cavity [17]. The film has a unique threelayered structure. The surface lipid layer produced by the meibomian gland can prevent the evaporation of the liquid. The water in the middle serves as a lubricant and the inner mucous layer secreted mainly by the conjunctival and corneal epithelium can keep the tear film closely attached to the ocular surface. The tear film, as the first encountered barrier of topical drugs, plays a predominant role in the dilution and excretion of drugs. The turnover rate of tear film under normal conditions is approximately $15 \% / \mathrm{min}$ in humans [18].

In-situ gel, cationic modification, viscous vehicle

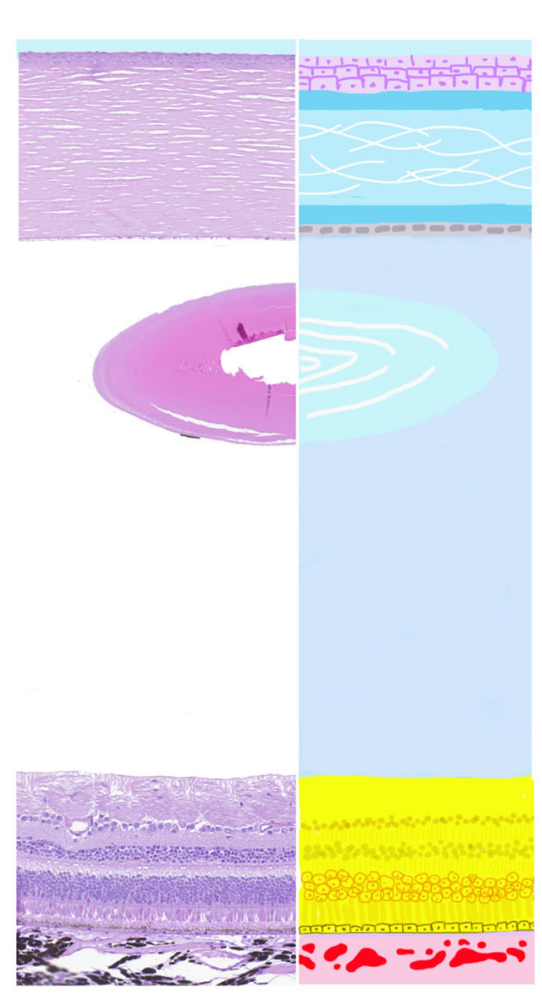

- Aqueous drainage Melanin-binding prodrugs

_ Vitreous reservoir Anionic modification (faster distribution), nanoparticle

Fig. 1 Schematic drawing of ocular drug barriers and common ways and formulations to bypass these barriers 
However, after the instillation of eye drops, the tear turnover rate instantly increases and most of the eye drops are lost to drainage in 15-30 s after application [19]. Thus, drugs administered as conventional eye drops have very short retention time on the ocular surface $[20,21]$, and a very limited amount (less than 5\%) of the drug molecules can penetrate into the eye [22]. The vast majority of drained drugs, however, can be reabsorbed by the nasal mucous membrane and are responsible for their systemic side effects [23].

One of the key principles of designing topical drugs is to avoid excessive tearing and extend the preocular retention time. To avoid irritation and further stimulation of lacrimation, topical formulations usually need to have the correct $\mathrm{pH}$ and osmolality. The ideal $\mathrm{pH}$ is close to the tear physiological $\mathrm{pH}$ of 7.4 , but $\mathrm{pH}$ 4.0-8.0 appears tolerable for human eyes [24]. The viscosity of eye drops is also a critical factor that can influence the speed of drainage [25], and adding viscous molecules is a common approach to increase the retention time of topical drugs, often with hydrophilic polymer polyvinyl alcohol, poloxamer, hyaluronic acid, carbomer, or cellulose [26]. However, high viscosity may disturb vision and become inconvenient when accurate vision is needed [27]. In addition, the proteins in the tear may bind to drugs and restrict their penetration. In particular, under inflammatory conditions, the tear protein increases which can lead to a more pronounced decrease in drug bioavailability [28]. In recent innovative formulations, other approaches have been tested, such as increasing the affinity of drugs to corneal cells or enhancing endocytosis, as summarized in the following text.

\section{Cornea and Sclera Block the Penetration of Drugs into the Eye}

The cornea and sclera are the rate-limiting barriers that block the penetration of drugs into intraocular tissues. In general, the cornea is the major route for the entry of topical lipophilic drugs, and the sclera is more permeable for hydrophilic molecules and proteins [29].
Different layers of the cornea have different barrier capacity and hydrophilicity [30]. The corneal epithelium in humans is composed of 6-7 layers of epithelial cells connected by tight junctions. This layer serves as a lipophilic barrier that restricts most hydrophilic drugs and molecules larger than $5 \mathrm{kDa}$ from entering the eye $[31,32]$. Corneal stroma and endothelium are more effective at limiting the penetration of small lipophilic drugs [33, 34]. However, compared with the epithelial barrier, the corneal stroma and endothelium are much less effective in blocking the drug molecules [35]. Thus, approaches to target the cornea barrier mainly focus on the enhancement of paracellular or transcellular uptake of drug molecules through the lipophilic corneal epithelium. Surface modification with cationic molecules (such as chitosan) is a common approach to enhance the corneal permeability and extend the retention time as the cornea is negatively charged $[36,37]$. In addition, multiple types of nanoparticles and the newly explored extracellular vesicles demonstrate improved transcellular uptake by corneal epithelium owing to their structural similarity to cell membranes and high affinity, which is discussed in more detail in "Innovations That Increase Intraocular Bioavailability of Topical Drugs" [38].

The sclera has a similar fibrous structure as the corneal stroma but is vascularized and covered by the loose fibrous layer of the conjunctiva. The sclera and conjunctiva have relatively higher drug permeability than the cornea and therefore are explored as alternative routes of topical drug delivery [30, 39]. However, far more drug molecules are absorbed by conjunctival circulation compared with those penetrated into the aqueous humor. This may explain the disproportional change between intraocular drug bioavailability and drug permeability across these barriers [40].

\section{Running Aqueous Humor Continuously Removes Intraocular Drugs}

Behind the cornea is the anterior chamber, which is filled with approximately $200 \mu \mathrm{l}$ of aqueous humor in humans [41]. The liquid has 
similar compositions to plasma except for a lower protein concentration [42]. The aqueous humor is constantly generated by the ciliary body and flows through the pupil into the anterior chamber and drains into the venous circulation at the anterior chamber angle. The turnover rate of human aqueous humor is $1.0-1.5 \% / \mathrm{min}$ [41], with variation between daytime (about $2 \mu \mathrm{l} / \mathrm{min}$ ) and nighttime (about $1 \mu \mathrm{l} / \mathrm{min}$ ) [43]. The drug molecules that pass through the ocular surface are first diluted in the aqueous humor and subsequently drained into the systemic circulation with aqueous humor outflow [44]. For drugs targeting the posterior eye, modification of drugs with surface molecules to enhance the binding with melanin to the uveal tract is a possible approach to resist excretion by aqueous drainage [45].

\section{Vitreous Body Dilutes Intraocular Drugs}

The vitreous body is the largest tissue in the eye with a total volume of around $5-6 \mathrm{ml}$ in adult humans $[46,47]$. This gel-like organ is mainly composed of water $(98 \%)$ with a density of $1.0053-1.0089 \mathrm{~g} / \mathrm{cm}^{3}[48,49]$ and contains glycosaminoglycans and type II collagen which form a complex network with an average pore size of $550 \mathrm{~nm}$ [50]. There are very limited phagocytes and hyaluronic cells to maintain low activities in this gelatinous tissue [51, 52].

As a result of its large volume and static physiology, drugs in the vitreous body are relatively stable. Topical drugs have to diffuse across this large static pool to reach the fundus, and the vitreous has distinct barrier functions depending on the properties of the drugs. Small drug molecules can move freely by passive diffusion [53]. As the vitreous network is also negatively charged, drug molecules with negative charges move faster, while drug molecules with positive charges move much more slowly and therefore have a relatively longer retention time $[50,54]$. Although the vitreous is highly viscous, the diffusivity of many small and anionic large molecules is even higher than in water $[55,56]$. Thus, for faster drug distribution to the fundus, modification with negative charges is preferred. The drug molecules can get eliminated either by diffusion to the retina/choroid (posterior approach) or the aqueous humor (anterior approach) [57]. As the reticular structure of vitreous collagens restricts the movement of large molecules, large molecular drugs generally have a long intravitreal half-life. Antibodies like ranibizumab and bevacizumab have a half-life in the vitreous of 3-7 days, while the small molecular drug ganciclovir has a halflife of less than $24 \mathrm{~h}$ [58-60]. In addition, the vitreous body contains a low level of enzymes and proteinases which can lead to the degradation and inactivation of drugs $[61,62]$. Thus, protection with nanoparticles may extend the drug effect time and is a preferred choice for the treatment of chronic diseases. As for translational considerations, the vitreous volume is very different between laboratory animals and humans as discussed in "Preclinical Models and Their Impacts on Translation of Novel Topical Formulations". One should be very careful when comparing the drug retention time in the vitreous between animals and humans [63].

In short, various ocular barriers, which either mechanically prevent drug molecules from entering the eye or continuously eliminate drugs within the eye, prevent topical drugs from reaching sufficient concentration in the intraocular tissues. This limitation becomes a bottleneck for topical drugs in the treatment of fundus diseases. The fast development of material sciences and technologies promotes the innovations of topical drug delivery and addresses the ocular barriers by different means. Recent results demonstrate the potential of different innovations in topical drug delivery for intraocular diseases.

\section{INNOVATIONS THAT INCREASE INTRAOCULAR BIOAVAILABILITY OF TOPICAL DRUGS}

As described above, various barriers prevent drugs from entering from the ocular surface and staying in the eye. Many new materials and technologies have been developed to overcome these obstacles (Fig. 1). Most of the explorations are still in the preclinical phases, but the results support their potential applications for clinical 
use. The following sections summarize the current progress of topical drug carriers for posterior delivery.

\section{Nanotechnology-Based Formulations}

Nanotechnology studies nano-sized materials from 1 to $100 \mathrm{~nm}$ and nanomedicine uses these particles for pharmaceutical and diagnostic purposes [64]. To date, about 50 nanomedical products have been approved by the US Food and Drug Administration (FDA), and more are in the preclinical and clinical phases [65]. In the field of ophthalmology, nanoparticles are also being explored as topical drug delivery tools (Table 1). In this section, we summarize the best-studied nanomedicines as topical ocular drug carriers.

\section{Nanovesicles (Liposomes and Niosomes)}

Nanovesicles are composed of a bilayered shell and a central core. The shell structure is similar to that of the cell membrane, which is composed of a double-layered amphiphilic membrane with hydrophobic tails facing inward and hydrophilic heads facing outward (Table 1). Owing to their high biocompatibility, nanovesicles have been tested as drug carriers to assist drug molecules through the corneal epithelial barriers $[66,67]$. The unique structure of nanovesicles allows them to carry either hydrophobic drugs between the hydrophobic space of bilayered shells or hydrophilic drugs and large biomolecules in the aqueous core [68]. On the basis of the compositions of shells, nanovesicles are divided into liposomes and niosomes $[67,69]$.

Liposomes are made of natural amphiphilic lipid molecules, such as phosphatidylcholine, phosphatidylethanolamine, and so on. Liposomal formulations of topical drugs have demonstrated promising results in improving both drug permeability and release time. A triamcinolone acetonide liposome eye drop could reach the aqueous humor and retinal surface within 6-10 min after instillation and ameliorated retinal edema in a rat model [70]. In addition, surface modification of bevacizumabloaded liposomes with annexin A5 was found to enhance the uptake and transcytosis of corneal epithelium. Topical application of this new formulation of bevacizumab could deliver therapeutic concentrations of the drug to the rat and rabbit retina [71].

Niosomes are made of nonionic surfactants. As the surfactants are neutrally charged, niosomes are less susceptible to oxidative degradation and therefore have longer shelf lives than liposomes [68, 72]. As with liposomes, niosomes have similar structures to the cell membrane and can reduce direct irritation of encapsulated drugs to the ocular surface [73]. A niosome formulation of doxycycline hyclate could release the drug component for up to 2 months in an in vitro system [74]. Pilocarpine hydrochloride niosome dispersed in gel formulation demonstrated better stability and drug release time in albino rabbits [75].

Although these preclinical studies have shown encouraging results, few such formulations have been developed into clinical use yet. Challenges include inadequate data on pharmacological properties to illuminate the impact of different drug-surfactant ratios, the relative amount of additives (cholesterol), vesicle size, surface charge, and surface modifications $[76,77]$. The poor stability and easy aggregation are potential issues, especially for large-scale production and long-term storage [78]. Some evidence suggests that liposomes may trigger certain innate immune reactions by activating the complement system [79]. A type of reaction called "complement activation-related pseudoallergy" has been reported in $25-45 \%$ of patients receiving intravenous liposomal drugs [80-82]. However, ocular toxicity associated with liposomes has not been reported up to now, presumably owing to the immune-privileged state of ocular tissues [83-85]. More basic and preclinical research will help to move forward their success for clinical use.

\section{Nanomicelles}

Nanomicelles are nano-sized spheres with a hydrophilic shell and a hydrophobic core (Table 1). The shell is formed of well-oriented surfactants and polymers, with hydrophilic heads facing outward and hydrophobic tails facing inside. Therefore, nanomicelles are 


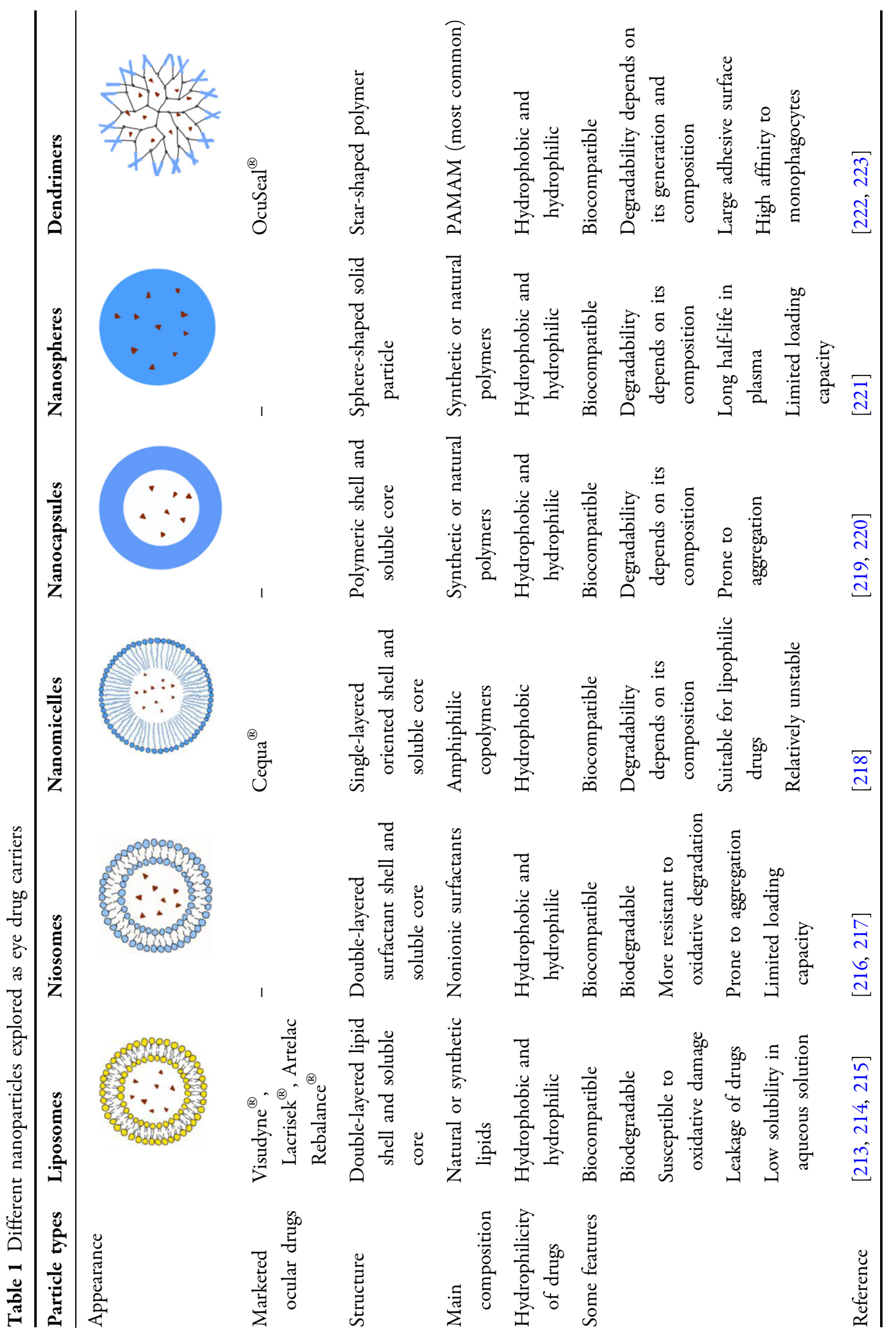


efficient carriers of hydrophobic drugs within their core space, such as dexamethasone, cyclosporine A, tacrolimus, rapamycin, etc. [86]. Nanomicelles demonstrate improved transcorneal permeability by increasing the contact time with corneal epithelial cells and inhibiting efflux pumps [87-90].

Eye drop formulations of nanomicelles have been tested for the treatment of retinal and choroidal diseases in animal models. A flurbiprofen nanomicelle eye drop had a tenfold increase of drug concentration in the aqueous humor compared with conventional eye drops [91]. A cyclosporine nanomicelle eye drop efficiently delivered the drug to the fundus of albino rabbits. The drug concentration in the retina and choroid was above the calculated therapeutic level [92]. Some concerns with the formulation have been discussed, such as the dilution effect of the tear film on the release kinetics of the drug and the potential toxic effect of nanomicelle polymers on retinal and choroidal cells [90, 93].

A successful product of nanomicelles formulation is Cequa ${ }^{\circledR}$ by Sun Pharma. This FDAapproved nanomicelle eye drop carries cyclosporine A $(0.09 \%)$ and is developed for the treatment of keratoconjunctivitis sicca. It showed a tenfold increase of cyclosporine A in the aqueous humor compared with conventional cyclosporine A solutions [94]. However, currently no topical nanomicelle formulation has been approved for the treatment of fundus diseases.

\section{Nanospheres and Nanocapsules}

Nanospheres and nanocapsules are polymeric particles with spherical shapes and diameters of 10-200 nm. Nanospheres carry drug molecules in the polymer matrix, and nanocapsules in the core (Table 1) [95, 96]. Nanospheres and nanocapsules are highly versatile and efficient. They can carry various drug molecules, from hydrophilic and hydrophobic molecules, peptides, proteins to genetic materials, by different means, either linked, entrapped, dissolved, or dispersed within the matrix/core $[66,97]$.

The polymeric nanoparticles can modify the activity of drugs by altering the physicochemical properties of the formulations, delay and control the drug release, and increase the drug adhesivity to the ocular surface [98]. These nanoparticles can be taken up by cells via endocytosis or pinocytosis and therefore assist drugs moving through ocular barriers and thus improve drug bioavailability [99-101]. Preclinical experiments have demonstrated that these polymeric particles could deliver topical drugs into the intraocular tissues. In a rabbit retinal degeneration model, melatonin delivered in topical ethylcellulose nanocapsule formulation demonstrated improved transcorneal permeability and neuroprotection effects [102]. Acyclovir nanosphere eye drop showed a sustained drug release curve and an increased drug concentration in rabbit aqueous humor. When modified with polyethylene glycol (PEG) coating, the $\mathrm{AUC}_{0-6 \mathrm{~h}}$ (area under the curve) of acyclovir further increased by another $80 \%$ in the aqueous humor [103].

Despite the high loading capacity and suitable pharmacokinetic properties, safety concerns are bottlenecks for their clinical application. Some reports show that polymeric materials of nanospheres and nanocapsules can interact with cell surface receptors, mitochondrial enzymes, and cytoplasmic proteins, which can cause stress responses and alteration of metabolic processes. Although polymers of nanospheres and nanocapsules are generally non-toxic to the ocular surface, the molecules may cause irritation and immune reactions, especially when applied in intraocular tissues [104, 105]. Poly(lactic-co-glycolic acid) (PLGA) nanocapsules have been found to cause cytoplasmic vacuole formation in rabbits [106]. Intravitreal injection of nude PLGA nanospheres could cause foreign body reactions and induction of monocyte chemoattractant protein 1 , macrophage inflammatory protein $1 \alpha$ (MIP-1 $\alpha$ ), MIP-1 $\beta$, interleukin-8, tumor necrosis factor- $\alpha$, interleukin- 6 , and interleukin-1ra in non-human primates [107]. Thus, nanospheres and nanocapsules are still in the early explorative phases and need more investigations for ocular use.

\section{Dendrimers}

Dendrimers are highly branched, star-shaped polymeric macromolecules with nanometer- 
scale dimensions (Table 1). These particles consist of a central core, interior dendritic structure (the branches), and exterior surfaces [108]. The core can carry either small molecules, macromolecules, or even genetic materials to ocular tissues $[109,110]$. The large surface area of the branches makes them bioadhesive to the extracellular matrix and cell surface receptors; therefore dendrimers have a long retention time on the ocular surface and can assist the penetration of carried drugs into the eye [111]. Their unique structures also extend the release time of drugs in the tissue [112].

One unique feature of dendrimers is their high affinity to the active monophagocytic system. Hydroxyl-end polyamidoamine (PAMAM) dendrimers were found to be enriched in activated macrophages, retinal microglial cells, astrocytes, and retinal pigment epithelium (RPE) in diseased eyes [112-115]. Once they enter the cells by endocytosis, the drug molecules in the dendrimers can be gradually released. For example, a cyanine dye in generation 4 hydroxyl-end PAMAM dendrimer formulation was administered into mice eyes with ischemia/reperfusion injury. The dye was retained in macrophages and microglial cells for over 21 days [113]. More sophisticated forms of dendrimers could even guide the drug to cell surface receptors such as integrin $\alpha \mathrm{v} \beta 3$ on the surface of the neovasculature [116]. Among the hundreds of types of dendrimers published, PAMAM-based dendrimers appear to be the most studied ones in ocular drug delivery [117].

To use dendrimers as potential drug carriers, more knowledge and experience are needed, such as how the composition, branching generation, terminal ends, charge, size, and surface radicals of dendrimers influence their stability, solubility, bioavailability, retention time, and their impacts on drug efficacy and safety $[117,118]$. In particular, dendrimers demonstrate ocular irritations which are dependent on their structures. PAMAM dendrimers with carboxyl or hydroxyl ends appear to be well tolerated and not immunogenic, but dendrimers with positively charged amino ends have some dose-dependent adverse effects [119, 120].

Besides the formulations mentioned above, many other forms of nanomedicines, including nanoemulsion [121], quantum dot [122], solid-lipid nanoparticle [123], and so on, have been investigated as topical ocular drug carriers and demonstrate beneficial efficacy. As an example, dexamethasone carried by soluble nanoparticle (drug name OCS-01) developed by Oculis is now in a phase III clinical trial for DME. The results of a phase II (DX-211) study demonstrated that OCS-01 as a topical eye drop formulation could significantly reduce central macular thickness and improve the visual acuity compared with the vehicle arm $[13,14]$.

To sum up, a variety of nanoparticles have been tested as ophthalmic drug carriers in animal eyes, and results showed that the nanoparticle formulations could increase the drug penetration through the ocular surface and/or extend drug retention time in the eyes. More investigations are needed to understand their nature, metabolism, and potential toxicities in the eye.

\section{In Situ Gelling Systems}

In situ gelling systems are polymeric formulations that switch from the initial solution form to gel form in the target tissue shortly after application. Commonly, the sol-gel transition is stimulated by $\mathrm{pH}$ change, temperature modulation, solvent exchange, ultraviolet irradiation, or the presence of specific ions or molecules (Table 2) [124]. For topical formulations, the sol-gel transition can slow down the clearance of drugs on the ocular surface. In ophthalmic application, the commonly used polymers were either sensitive to temperature (poloxamers, hydroxypropyl methylcellulose, and xyloglucan), $\mathrm{pH}$ (polyacrylic acid), or ions (gellan gum, alginic acid, and carrageenan) [125].

Several in situ gelling systems have been successfully translated into ocular drugs, such as Akten $^{\circledR}$ (lidocaine hydrochloride), Pilopine HS ${ }^{\circledR}$ (pilocarpine hydrochloride ocular gel), Virgan ${ }^{\circledR}$ (ganciclovir), and Timoptic-XE ${ }^{\circledR}$ (timolol maleate ocular gel-forming solution) [126]. And more in situ gelling systems are under development. One type of ciprofloxacin hydrochloride eye drop is a thermosensitive and $\mathrm{pH}$-responsive 
Table 2 Recent application of in situ gelling systems in topical formulations

\begin{tabular}{|c|c|c|c|c|c|}
\hline Drugs & $\begin{array}{l}\text { Designed } \\
\text { indications }\end{array}$ & Stimuli & Gelling agents & Chief study results & Reference \\
\hline Acetazolamide & Glaucoma & $T \sim 35^{\circ} \mathrm{C}$ & $25 \%$ Pluronic F-127 & Drug released for over $6 \mathrm{~h}$ & {$[224]$} \\
\hline $\begin{array}{l}\text { Betaxolol } \\
\text { hydrochloride }\end{array}$ & Glaucoma & $T \sim 33{ }^{\circ} \mathrm{C}$ & $\begin{array}{l}\text { Poloxamer } 407 \text { and } \\
\text { methylcellulose }\end{array}$ & $\begin{array}{c}>80 \% \text { of drugs released } \\
\text { within } 12 \mathrm{~h}\end{array}$ & {$[225]$} \\
\hline Levofloxacin & $\begin{array}{l}\text { Ocular bacterial } \\
\text { infection }\end{array}$ & $T \sim 32{ }^{\circ} \mathrm{C}$ & $\begin{array}{l}\text { Hexanoyl glycol } \\
\text { chitosan }\end{array}$ & $\begin{array}{l}\text { Drug released for over } 12 \mathrm{~h} \\
\text { Precorneal retention time } \\
\text { over } 30 \mathrm{~min}\end{array}$ & {$[226]$} \\
\hline $\begin{array}{l}\text { Dorzolamide } \\
\text { chloride }\end{array}$ & Glaucoma & $\mathrm{pH} \sim 7.4$ & $\begin{array}{l}\text { Carbopol }^{\circledR} \text { and } \\
\text { hydroxyl propyl } \\
\text { methyl cellulose } \\
\text { (HPMC) }\end{array}$ & Drug released for over $8 \mathrm{~h}$ & {$[227]$} \\
\hline Levofloxacin & $\begin{array}{l}\text { Ocular bacterial } \\
\text { infection }\end{array}$ & $\mathrm{pH} \sim 7.4$ & $\begin{array}{l}\text { HPMC and sodium } \\
\text { alginate }\end{array}$ & $\begin{array}{l}94 \% \text { of drug released within } \\
24 \mathrm{~h}\end{array}$ & {$[228]$} \\
\hline Moxifloxacin & $\begin{array}{l}\text { Ocular bacterial } \\
\text { infection }\end{array}$ & $\mathrm{pH} \sim 7.4$ & $\begin{array}{l}\text { Terminalia arjuna bark } \\
\text { resin gum and } \\
\text { alginate }\end{array}$ & Drug released for over $12 \mathrm{~h}$ & [229] \\
\hline Nepafenac & Postoperative pain & $\begin{array}{l}\text { Divalent } \\
\text { cations }\end{array}$ & $\begin{array}{l}\text { Sodium alginate and } \\
\text { Protanal PH } 1033\end{array}$ & $\begin{array}{l}\text { Corneal permeability } \\
\text { increased by 14-fold } \\
\text { compared with simple } \\
\text { solution }\end{array}$ & {$[230]$} \\
\hline $\begin{array}{l}\text { Phenylephrine } \\
\text { and } \\
\text { tropicamide }\end{array}$ & $\begin{array}{l}\text { Induce mydriasis for } \\
\text { ocular } \\
\text { examination and } \\
\text { surgery }\end{array}$ & $\begin{array}{l}\text { Mono- and } \\
\text { divalent } \\
\text { cations }\end{array}$ & $\begin{array}{l}\text { Gellan gum and } \\
\text { hydroxyethylcellulose }\end{array}$ & $\begin{array}{l}80 \% \text { of drugs released within } \\
30-180 \mathrm{~min}\end{array}$ & {$[231]$} \\
\hline Brinzolamide & Glaucoma & $\begin{array}{l}\text { Mono- and } \\
\text { divalent } \\
\text { cations }\end{array}$ & $\begin{array}{l}\text { Deacetylated gellan } \\
\text { gum }\end{array}$ & $\begin{array}{l}90 \% \text { drugs released over } \\
16-19 \mathrm{~h}\end{array}$ & {$[232]$} \\
\hline
\end{tabular}

in situ gelling formulation, and the drug in the formulation could be detected on the ocular surface for $8 \mathrm{~h}$ [127]. A compound formulation of in situ gel and nanoparticle was found to deliver disulfiram to the rat retina and rescued retinal dysfunction in a diabetic model by repeated topical instillation [128]. Some large molecules and genetic materials are also being tested with in situ gelling systems in preclinical and clinical studies [125, 129].

In addition to the improvement of the bioavailability and the permeability of drugs, in situ gelling formulations are often transparent and therefore have less visual disturbance compared to micelles or ointments [130]. Most of the polymers used for in situ gelling systems are non-toxic, biocompatible, and self-degradable, and their short-term application appears to be safe $[131,132]$.

\section{Iontophoresis and Sonophoresis}

Iontophoresis and sonophoresis are a group of techniques that apply the physical force of an electric or acoustic field to enhance the 
penetration of drug molecules across cellular barriers [133]. These approaches are particularly useful for the delivery of antibiotics, antiviral agents, steroids, as well as proteins into the eye [134].

Iontophoresis uses an electric current to drive ionized particles through the normal cellular barrier [135-137]. The electrodes are often placed on the surface of the cornea or sclera as they have relatively high water contents and low tissue resistance and can stand relatively higher current intensity [138]. Some iontophoresis devices, such as EyeGate ${ }^{\circledR}$, OcuPhor $^{\mathrm{TM}}$, and Visulex ${ }^{\mathrm{TM}}$, have been developed for ocular applications in humans [139, 140]. The upper limit of current density and duration are usually within $1.8 \mathrm{~mA} / \mathrm{cm}^{2}$ for $5 \mathrm{~min}$ for corneal application, and $5.5 \mathrm{~mA} / \mathrm{cm}^{2}$ for $20 \mathrm{~min}$ for scleral application [134, 141]. The procedure can cause transient but bearable irritations, and some reversible epithelial lesions [141]. Iontophoresis is effective for the intraocular delivery of both small and large molecules. In a rabbit choroidal neovascularization (CNV) model, approximately $0.6 \mathrm{mg}$ of bevacizumab could be delivered into the rabbit eye by transscleral iontophoresis and the development of retinal neovascularization was delayed by 4 weeks [142].

Sonophoresis is an ultrasound-based technique that creates tiny cavitations in cells that act as permeable channels for drug movement [143]. This technique was used 60 years ago for the absorption of hydrocortisone in skin tissues [144]. In the ocular test, sonophoresis showed a 1.6-fold increase of the penetration efficacy of fluorescein isothiocyanate-labeled bovine albumin through excised rabbit sclera, without observable histological adverse changes [145]. Similarly, sonophoresis could help the penetration of different sizes of dextran $(20-150 \mathrm{kDa})$ through the cornea [146]. The drug depots in cavitations of the eye surface tissues act like tiny reservoirs and could slowly release drug molecules into the aqueous or vitreous humor [133]. Future ocular studies need to further evaluate the impacts of overheating effect due to energy absorption and the redistribution effect by aqueous flow and choroidal vascular circulation [147-149].

\section{Microneedles}

Microneedles apply mechanical force to generate multiple tiny holes on the tissue surface that effectively help deliver drugs through tissue barriers such as skin, cornea, and sclera. There are different types of microneedles as illustrated in Fig. 2. Solid microneedles are often made of stainless steel, titanium, or silicon, which are applied on the surfaces of the cornea or sclera to enhance the penetration of drugs. Other types of microneedles include drug-coated microneedles, dissolvable microneedles (made of biodegradable materials), and hollow microneedles (with a channel inside which is connected to a syringe or pump).

Intracorneal and intrascleral microneedles are often used to assist the penetration and retention of topical drugs by physically interrupting the epithelial barriers to improve intraocular drug bioavailability. The tiny sizes of microneedles make them generally minimally-invasive to the ocular surface. For example, a type of dissolvable microneedle containing besifloxacin was able to deliver over $55 \%$ of the drug across the corneal barrier over $24 \mathrm{~h}$. The microneedle could spontaneously dissolve within the cornea in $25 \mathrm{~min}$ [150]. A dissolvable trans-sceral microneedle could enhance trans-scleral penetration of dextrans at the size of $150 \mathrm{kDa}$ from $6 \%$ to $100 \%$ compared with the simple solution [151]. These data suggest that when used in combination with topical drugs, microneedles can effectively promote their penetration, even for macromolecules. However, it should be noted that most of the current studies only explore their efficacy for anterior segment diseases, and the efficacy data for retinal and choroidal disorders are lacking. Future studies need to further explore their potential applications for posterior segment diseases and address the long-term impacts of repeated applications of intracorneal microneedles on the biomechanical properties of the cornea. 
a

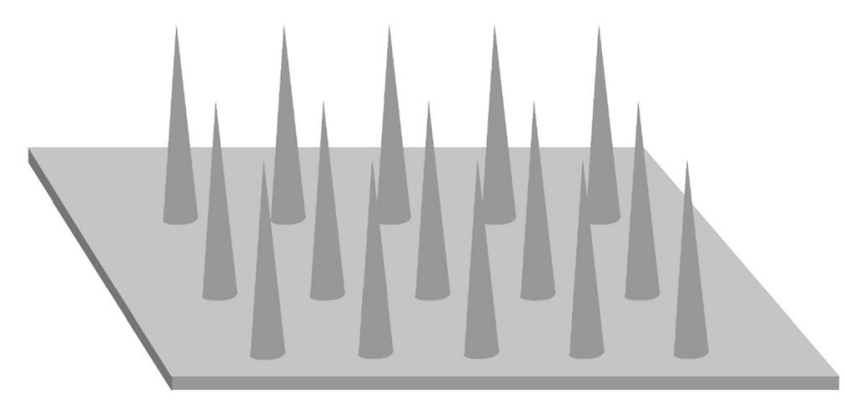

b

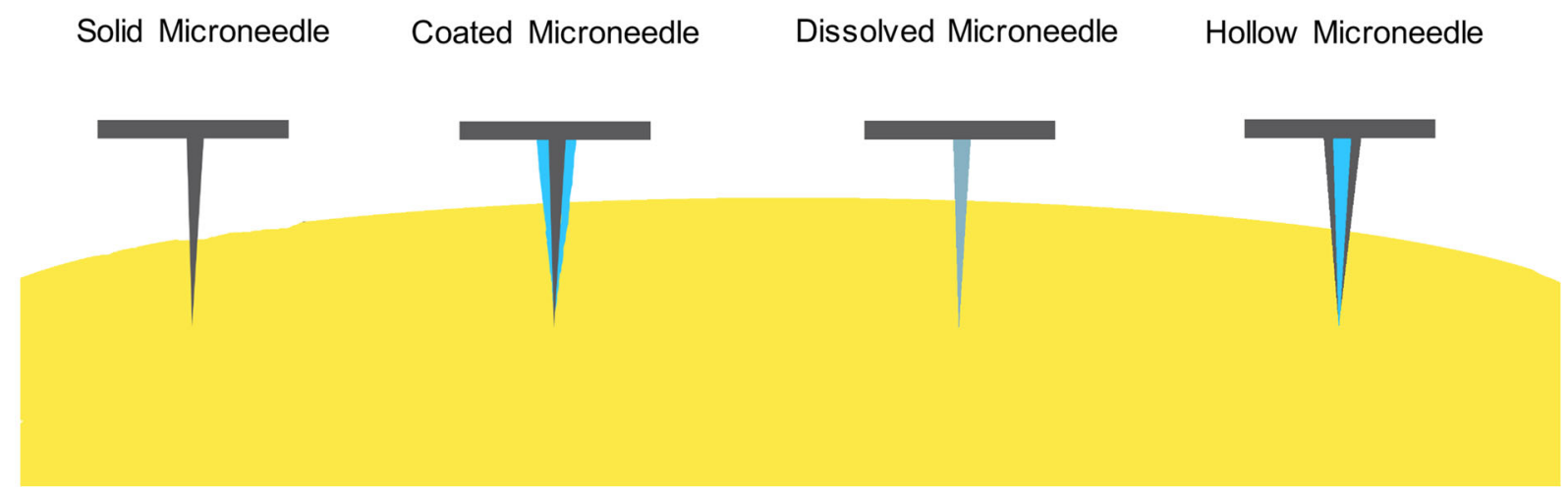

Fig. 2 Schematic of different types of microneedles used for drug delivery. a A microneedle patch; $\mathbf{b}$ detailed structures of different microneedles, including solid, drug-coated, dissolved, and hollow microneedles

\section{Cell-Penetrating Peptides}

The corneal epithelium has active endocytosis activity which may act as a gateway for drug entry [152]. There are four types of endocytosis in general, i.e., phagocytosis, macropinocytosis, clathrin-mediated endocytosis, and caveolinmediated endocytosis, and their activities are essential for maintaining normal functions of the eye [153]. Stimulation of these endocytosis activities by cell-penetrating peptides, folic acid-binding, transferrin, and hyaluronic acid coating can facilitate the penetration of topical drugs through the corneal epithelial barriers $[154,155]$.

Cell-penetrating peptides are a group of short peptides containing abundant positively charged amino acids, which can enhance the transcorneal permeability of drugs [156]. Some preclinical studies demonstrated that cell-penetrating peptides could help large molecular drugs in eye drops reach the posterior segment in animal eyes [157-159]. An eye drop formulation of acidic fibroblast growth factor coupled with a cell-penetrating peptide named transactivator of transcription (TAT) was applied topically to a rat model of retinal ischemia/ reperfusion injury. The drug was detected in the retina $8 \mathrm{~h}$ after topical dosing, and the protective effect on ganglion cells was evident [157]. An eye drop formulation of bevacizumab and ranibizumab coupled with cell-penetrating peptides was topically administered to a laserinduced CNV rat model, and the results showed similar efficacy to that from the drug administered intravitreally [158]. It should be noted that these promising results were largely limited in small animals so far.

There are many remaining challenges in the translation of cell-penetrating peptides into clinical use. Some essential questions need to be answered, such as how to control the selectivity of drug penetration and avoid the unspecific 
enhancement, and how to prevent the fast degradation of the peptides by the intracellular protease system [160]. In addition, certain drugs may form complexes and be stored in intracellular vesicles or escape into the cytoplasm after endocytosis, which may cause potential toxicity [155].

\section{Extracellular Vesicles}

Extracellular vesicles (EVs) are a broad range of biological particles released from cells, including exosomes, ectosomes, microvesicles, microparticles, oncosomes, and apoptotic bodies, with sizes ranging from 30 to $10,000 \mathrm{~nm}$ in diameter [161]. EVs can be generated by direct outward budding of the plasma membrane (microvesicles) or inward budding of the endosomal membrane and subsequent release from cells (exosomes) [162]. Natural EVs carry a variety of cargos from their source cells, such as mRNA, miRNA, DNA, proteins, and lipids, and may participate in many biological processes, including cell-cell communication, remote signaling, immunomodulation, substance delivery, and even apoptosis [163, 164]. Immunologically active exosomes have been found to regulate innate and adaptive immune responses [165]. Thus, EVs can naturally be a part of the regimen for many ocular inflammatory conditions [166-169].

EVs as natural components of cells have the highest tissue biocompatibility, low immunogenicity, and low toxicity, and therefore are ideal drug carriers if possible. Therapeutic molecules can be loaded into the EVs via exogenous loading or endogenous packaging processes [170]. Although EVs have been extensively explored as potential drug carriers in many fields, their ocular application as drug carriers is still in the initial exploration stage. In animal models, drugs loaded by EVs given by intraocular injection demonstrate widespread and homogenous distribution in the fundus, which was superior to conventional carriers $[171,172]$. On the basis of the experience gained from nanoparticles, it is reasonable to infer that EVs may also have potential benefits as a topical formulation for posterior segment diseases, which require further explorations.

More investigations on the contents, cell distribution, ocular tissue tropism, penetrating capacity, and interaction with host cells will help the clinical translation of EVs [173]. The uptake of EVs by target cells is also affected by the sizes, charge, and ionic strength of the surrounding environment and should be optimized for clinical application [174]. One of the major safety concerns with EVs is related to their natural components, as EVs are mainly harvested from immortalized cells or stem cells, which may carry oncogenic materials [170]. In addition, introducing donor EVs into host cells could disturb their normal environment [175]. However, current data did not show any obvious adverse effect of EVs-based therapy in animals [176] and humans [177-180].

As a type of new platform, EVs also face manufacturing challenges. At the moment, EVs can only be generated in cultured cells and scale-up preparation needs more innovations [181]. A good manufacturing practice (GMP)grade method for scale-up generation of EVs from human cardiac progenitor cells has been reported [182]. Recently some companies are using technologies based on chromatography and filtration, and candidate products are being tested in clinical trials [183].

In summary, multiple new platforms and formulations have been tested and applied for topical ocular drugs to reach the posterior segment. The mechanisms to overcome ocular barriers include both active approaches (enhancement of endocytosis, binding with corneal surface, or inhibition of efflux activity) and passive approaches (physical breakdown of epithelial barriers, or movement driven by physical forces). The choice of the platforms for topical drugs should consider the internal properties of the drug molecules (size, charge, hydrophilicity, ocular irritation, etc.), indications, demand for sustained release, availability of equipment for drug administration, and the acceptability of patients and ophthalmology clinicians. 


\section{PRECLINICAL MODELS AND THEIR IMPACTS ON TRANSLATION OF NOVEL TOPICAL FORMULATIONS}

Laboratory animals are the major tools for the preclinical evaluation of new drug molecules including topical formulations. These tools were used to demonstrate promising efficacy and good accessibility to the fundus of rodents of numerous topical small molecular drugs, such as TG100801, pazopanib, acrizanib, regorafenib, and OT-551 [16, 184-191]. However, these drug molecules failed to achieve similar efficacy and therapeutic concentration in patients. These failures remind us of the difference between animal eyes and human eyes. An in-depth understanding of comparative eye anatomy is crucial for species selection and data translation obtained from animal models. The fast development of in vitro human eye models will serve as alternative tools for the evaluation of topical eye drugs in the future.

\section{In Vivo Models: Be Aware of Differences Between Animal Eyes and Human Eyes}

Animal models have been applied in many ophthalmological studies [192]. Commonly used laboratory animals for ocular pharmacological research include mice, rats, rabbits, monkeys, and occasionally dogs, pigs, etc. Small laboratory animals are more often selected as test species, especially for small molecular drugs, presumably owing to lower cost, broader test options, and easier availability of housing conditions. However, some data demonstrate that small eyes have poor clinical predictability of topical drugs [186, 193]. As an example, regorafenib and pazopanib are small molecular inhibitors of vascular VEGF receptors and were given topically to treat $\mathrm{CNV}$ in animal models. Both drug molecules achieved desirable therapeutic concentrations in rat fundus and inhibited $\mathrm{CNV}$ in a rat model. However, similar pharmacokinetics and efficacy results were not achieved in rabbit and monkey eyes [184]. A phase II clinical trial of regorafenib eye drops for neovascular age-related macular degeneration (AMD) was terminated because of inferior efficacy compared with current nAMD therapy, presumably as a result of insufficient drug exposure to the posterior segment [185]. This example highlights that the differences between animal and human eyes need to be fully understood.

To visualize the anatomical differences, we collected globes of healthy mice $(\mathrm{C} 57 \mathrm{BL} / 6 \mathrm{~J})$, rats (Sprague-Dawley), rabbits (New Zealand White), dogs (beagles), and monkeys (cynomolgus), which were fixed with $10 \%$ formalin, embedded in paraffin, sectioned at 4-mm thickness, and stained with hematoxylin-eosin. Representative slides at similar sectional planes were scanned with a digital slide scanner (Leica, USA) with the same amplification. The study was approved by the Institutional Animal Care and Use Committee (IACUC) of National Chengdu New Drug Safety Evaluation Center, and the procedure followed the Association for Research in Vision and Ophthalmology (ARVO) Statement for the Use of Animals in Ophthalmic and Vision Research. Representative images of the eyes are shown in Fig. 3, which visualizes remarkable differences in globe size and major structural compositions of the eyes of different laboratory animals. The differences in the axial length, the thickness of cornea and sclera, and the volume of vitreous are all potential factors that affect the bioavailability and accessibility of topical eye drugs at the fundus of the eye. Taking the vitreous volume as an example, the difference between rodent and human eyes could even exceed one thousand times (see detailed figures in Table 3). This remarkable difference may significantly affect the intraocular concentration of small molecule drugs delivered via eye drops.

The differences among species not only include structural parameters but also dynamic physical activities as summarized in Table 3. Some physiological factors can also influence topical drug concentration in animal and human eyes. Take the rabbit eye as an example: it has a very lower blink rate that can influence drug retention time on the ocular surface and drug penetration rate into the eye. Obviously, no animal eye is identical to the human eye. To 


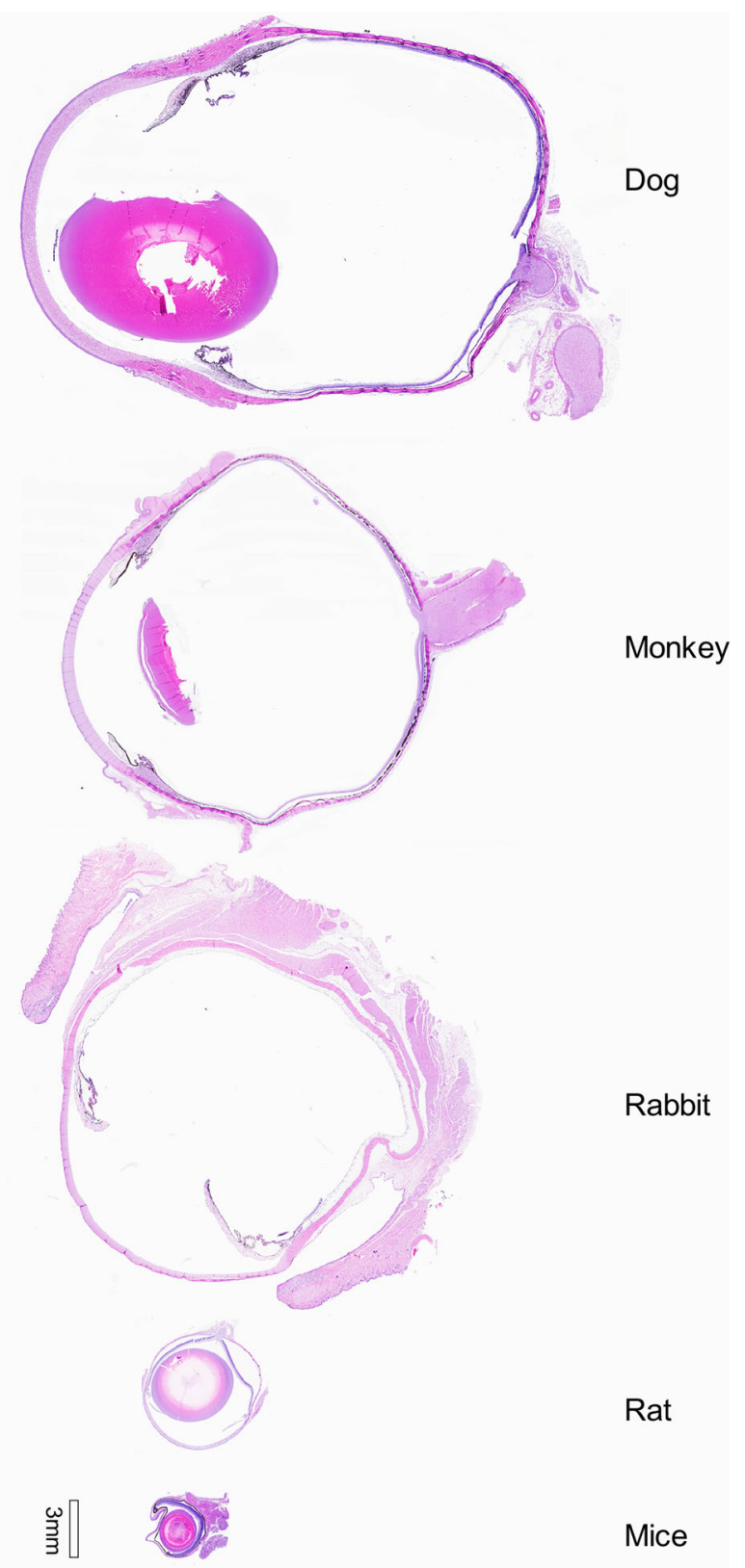

Fig. 3 Comparison of the globe structures of different laboratory animals

increase the translation rate of topical eye drugs for fundus diseases, one should have an indepth knowledge of the anatomical and physical features of human and animal eyes to take a rational selection of suitable laboratory animals as the preclinical test model. When using preclinical data to determine the dose range one needs to make appropriate adjustment based on anatomical and physiological differences of animal eyes and human eyes.

\section{In Vitro Models: Emerging Tools for Ocular Drug Testing}

In recent years, the fast development of human embryonic stem cell technology makes it possible to construct eye models in vitro. These models are rationally simplified human eyes which can mimic parts of the structural, physical, or pathological features of the human eye.

3D bioprinting uses inkjet-based printing approaches to build the 3D scaffolds which allow cells to reside [194]. Some tissue structures, such as skin, muscle, and liver tissues, have been created by 3D bioprinting [194-197]. In ocular application, 3D bioprinting has been successfully applied to reconstruct the structures of the cornea in vitro and shows promising results in retina bioengineering. Different corneal models, either containing a specific layer (stroma) or the intact cornea, have been printed with viable cells derived from humans $[198,199]$. The bioprinting of the retina is extremely challenging because of its multiple cellular composition and complex structure. Currently, no complete retinal structure based on 3D bioprinting has been constructed but some researchers have created retinal models containing several specific layers [200, 201]. These $3 \mathrm{D}$ bioprinting models provide a new tool for in vitro drug testing in a human-like environment.

Organoids are tiny, self-organized 3D tissue cultures that are derived from stem cells. The cultures can recapitulate some structural and functional features of the organ and also simulate pathological conditions [202, 203]. As these organs can be derived from the patient and survive for up to several months in vitro, they can provide valuable information to observe personalized reactions to the drugs [204]. As an example, a corneal organoid was developed from human induced pluripotent stem cells. The stem cells underwent multiple differentiation programs and formed 3D corneal structures with functional layers of the epithelium, stroma, and endothelium [205]. Retinal 
Table 3 Comparison of static and dynamic features of human eyes with commonly used laboratory animals

\begin{tabular}{|c|c|c|c|c|c|}
\hline & Mice & Rat & Rabbit & $\begin{array}{l}\text { Rhesus } \\
\text { monkey }\end{array}$ & Human \\
\hline \multicolumn{6}{|l|}{ Static parameters } \\
\hline Corneal diameter $(\mathrm{mm})$ & $\begin{array}{r}2.3-2.6 \\
{[233]}\end{array}$ & $\begin{array}{l}5.8 \\
\quad[234]\end{array}$ & $\begin{array}{l}\text { Horizontal } 13.4 \\
\text { Vertical } 13.0 \\
\text { [235] }\end{array}$ & $\begin{array}{l}\text { Horizontal } \\
\qquad 11.4 \\
\text { Vertical } 10.8 \\
\quad[236]\end{array}$ & $\begin{array}{l}\text { Horizontal } \\
\qquad 11.8 \\
\text { Vertical } 11.3 \\
\text { [237] }\end{array}$ \\
\hline Central corneal thickness $(\mu \mathrm{m})$ & $\begin{array}{c}123-134 \\
{[233]}\end{array}$ & $\begin{array}{c}159 \pm 15 \\
{[238]}\end{array}$ & $\begin{array}{c}349-384 \\
{[239]}\end{array}$ & $\begin{array}{c}520 \pm 5 \\
{[240]}\end{array}$ & $\begin{array}{c}548 \pm 35 \\
{[241]}\end{array}$ \\
\hline Anterior chamber depth $(\mathrm{mm})$ & $\begin{array}{l}0.31 \\
\quad[242]\end{array}$ & $\begin{array}{l}0.87 \\
\quad[243]\end{array}$ & $\begin{array}{l}2.90 \\
\quad[244]\end{array}$ & $\begin{array}{l}3.51 \\
\quad[245]\end{array}$ & $\begin{array}{l}3.05 \\
\quad[246]\end{array}$ \\
\hline Ocular axis length $(\mathrm{mm})$ & $\begin{array}{l}3.0 \\
\quad[242]\end{array}$ & $\begin{array}{l}6.0 \\
\quad[243]\end{array}$ & $\begin{array}{l}18.1 \\
\quad[244]\end{array}$ & $\begin{array}{l}20.3 \\
{[236]}\end{array}$ & $\begin{array}{l}23.9 \\
{[246]}\end{array}$ \\
\hline Anterior chamber depth/ocular axis & 0.10 & 0.14 & 0.16 & 0.17 & 0.13 \\
\hline Anterior chamber volume $(\mu \mathrm{l})$ & $\begin{array}{c}2.39-3.08 \\
{[247]}\end{array}$ & $\begin{array}{c}\sim 15 \\
{[248]}\end{array}$ & $\sim 250$ & $\begin{array}{c}134 \pm 5 \\
{[249]}\end{array}$ & $\begin{array}{c}153 \pm 27 \\
{[250]}\end{array}$ \\
\hline Total aqueous volume $(\mu \mathrm{l})$ & $\begin{array}{c}5.9 \pm 0.5 \\
{[251]}\end{array}$ & $\begin{array}{c}13.1 \pm 3.8 \\
{[248]}\end{array}$ & $\begin{array}{l}287 \\
{[252]}\end{array}$ & $\begin{array}{c}220 \pm 15 \\
{[249]}\end{array}$ & $\begin{array}{l}260 \\
{[41]}\end{array}$ \\
\hline Vitreous chamber depth $(\mathrm{mm})$ & $\begin{array}{l}0.71 \\
\quad[242]\end{array}$ & $\begin{array}{l}1.51 \\
\quad[243]\end{array}$ & $\begin{array}{l}6.20 \\
{[244]}\end{array}$ & $\begin{array}{l}12.42 \\
{[245]}\end{array}$ & $\begin{array}{l}16.32 \\
{[246]}\end{array}$ \\
\hline Vitreous chamber depth/ocular axis & 0.24 & 0.25 & 0.34 & 0.61 & 0.68 \\
\hline Vitreous volume $(\mu \mathrm{l})$ & $\begin{array}{c}4.4 \pm 0.7 \\
{[253]}\end{array}$ & $\begin{array}{c}13.4 \pm 0.6 \\
{[254]}\end{array}$ & $\begin{array}{c}\sim 1400 \\
{[255]}\end{array}$ & $\begin{array}{c}3300-3700 \\
{[256]}\end{array}$ & $\begin{array}{c}\sim 4400 \\
{[257]}\end{array}$ \\
\hline Lens thickness $(\mathrm{mm})$ & 1.6 & $\begin{array}{l}3.9 \\
\quad[243]\end{array}$ & $\begin{array}{l}7.9 \\
\quad[244]\end{array}$ & $\begin{array}{l}3.8 \\
{[245]}\end{array}$ & $\begin{array}{l}4.0 \\
\quad[246]\end{array}$ \\
\hline Retinal thickness $(\mu \mathrm{m})$ & $\begin{array}{l}204 \\
\quad[258]\end{array}$ & $\begin{array}{c}219-236 \\
{[259]}\end{array}$ & $\begin{array}{c}\text { Vascular area } \\
163-340 \\
\text { Avascular area } \\
142-168 \\
{[259]}\end{array}$ & $\begin{array}{l}223 \\
\quad[260]\end{array}$ & $\begin{array}{c}190-276 \\
{[261]}\end{array}$ \\
\hline \multicolumn{6}{|l|}{ Dynamic parameters } \\
\hline Blink intervals (s) & $\begin{array}{l}300 \\
\quad[262]\end{array}$ & $\begin{array}{l}300 \\
\quad[262]\end{array}$ & $\begin{array}{l}360 \\
{[262]}\end{array}$ & $\begin{array}{l}6 \\
{[262]}\end{array}$ & $\begin{array}{l}5 \\
{[262]}\end{array}$ \\
\hline Tear secretion rate $(\mu \mathrm{l} / \mathrm{min})$ & & & $\begin{array}{l}0.5 \\
\quad[263]\end{array}$ & & $\begin{array}{l}0.7-1.2 \\
\quad[264,265]\end{array}$ \\
\hline Residual tear volume $(\mu \mathrm{l})$ & $\begin{array}{c}0.06-0.20 \\
{[266]}\end{array}$ & $\begin{array}{l}4.6 \\
\quad[267]\end{array}$ & $\begin{array}{c}7.5 \pm 2.5 \\
{[263]}\end{array}$ & & $7.0-12.4$ \\
\hline
\end{tabular}


Table 3 continued

\begin{tabular}{lccccc}
\hline & Mice & Rat & Rabbit & $\begin{array}{l}\text { Rhesus } \\
\text { monkey }\end{array}$ & Human \\
\hline Tear turnover rate (\%/min) & 5.2 & & 7.1 & & 16.0 \\
& {$[268]$} & & {$[263]$} & & {$[265]$} \\
Rate of aqueous humor production & $0.18 \pm 0.05$ & $0.35 \pm 0.11$ & $1.46-1.71$ & $4.54 \pm 1.11$ & $2.40 \pm 0.60$ \\
$(\mu \mathrm{l} /$ min) & {$[251]$} & {$[248]$} & {$[239]$} & {$[240]$} & {$[41]$} \\
Aqueous humor turnover rate $(\% /$ & 2.5 & 2.2 & 1.6 & 2.0 & $1.0-1.5$ \\
min) & {$[251]$} & {$[248]$} & {$[252]$} & {$[240]$} & {$[41]$} \\
\hline
\end{tabular}

organoids are much more complicated and are still under development. These organoids are often generated from mice or human embryonic stem cells and are composed of either the outer layers of the retina (rods and cones with photosensitivity activity) or the inner layers of the retina (stratified layers of neural retina) [206-208]. These in vitro organs are useful for drug testing and prediction of the response of the patient to a specific therapy.

The organ-on-a-chip (OoC) system is a multichannel 3D microfluidic cell culture chip that simulates the activities, mechanics, and physiological responses of the entire organ or organ systems [209]. OoC provides the opportunity to study the effects of dynamic physiological activities on drug distribution and bioavailability, such as vascular drainage, lacrimation, and blinking [210]. In an OoC model of the ocular surface, the system was composed of functional corneal and conjunctival epithelium and an electric-actuated hydrogel-made eyelid. The different parts were connected with multiple channels to mimic tear generation during blinking [211]. In a recently reported OoC which was used to simulate the pathological features of $\mathrm{nAMD}$, the system consisted of a layer of RPE and adjacent blood vessel network which showed the intact blood-retinal barrier function. Addition of VEGF to the culture media induced sprouting of blood vessels into the PRE layer, which could be inhibited by bevacizumab [212]. OoC has also been applied to observe retinal drug toxicity on functional retinal cells [213].
Taken together, the use of topical ocular formulations to treat chronic fundus diseases is a very attractive and very difficult concept. The novel testing technologies such as OoC, organoids, and 3D bioprinting are still in the early phase of development and their applications on in vitro drug testing need further validation.

\section{CONCLUSIONS}

Intraocular drug delivery is one of the most challenging fields in ocular drug research and development (R\&D) as a result of the unique structure of the eye. The solutions depend on brave innovations and scientific tests. The development of new material and technologies has brought possibilities to create new topical formulations. The test models are critical to guarantee the clinical translationality of new topical formulations.

\section{ACKNOWLEDGEMENTS}

We thank Dr. Qiu Shuang of WestChina-Frontier Pharmatech Co. Ltd. for her kind assistance in the histology study.

Funding. Dr. Lixiang Wang is funded by the post-doctoral research funding of West China Hospital, Sichuan University, China (Grant number 2020HXBH044) and the Science \& Technology Department of Sichuan Province (China) funding project (No. 2021YFS0221). Mikael Ben Zhou is funded by the summer 
scholarship of Lund university, Sweden. These funds collectively supported the language editing service fee. The rapid service fee and open access fee were supported by Yuanpu Eye Biopharmaceutical Co. Ltd., China.

Authorship. All named authors meet the International Committee of Medical Journal Editors (ICMJE) criteria for authorship for this article, take responsibility for the integrity of the work as a whole, and have given their approval for this version to be published.

Authorship Contributions. Lixiang Wang and Mikael Ben Zhou conducted literature studying and drafting of the manuscript. Hui Zhang proposed the outline and revised the manuscript.

Disclosures. Lixiang Wang, Mikael Ben Zhou and Zhang Hui have nothing to declare.

Compliance with Ethics Guidelines. This article does not include new studies with human participants conducted by any of the authors. The animal study was approved by Institutional Animal Care and Use Committee (IACUC) of National Chengdu New Drug Safety Evaluation Center. All study procedures followed the Association for Research in Vision and Ophthalmology (ARVO) Statement for the Use of Animals in Ophthalmic and Vision Research.

Data Availability. Data sharing is not applicable to this article as no datasets were generated or analyzed during the current study.

Open Access. This article is licensed under a Creative Commons Attribution-NonCommercial 4.0 International License, which permits any non-commercial use, sharing, adaptation, distribution and reproduction in any medium or format, as long as you give appropriate credit to the original author(s) and the source, provide a link to the Creative Commons licence, and indicate if changes were made. The images or other third party material in this article are included in the article's Creative Commons licence, unless indicated otherwise in a credit line to the material. If material is not included in the article's Creative Commons licence and your intended use is not permitted by statutory regulation or exceeds the permitted use, you will need to obtain permission directly from the copyright holder. To view a copy of this licence, visit http://creativecommons.org/licenses/by$\mathrm{nc} / 4.0 /$.

\section{REFERENCES}

1. World Health Organization. World report on vision. Geneva: World Health Organization; 2019.

2. Dafer RM, Schneck M, Friberg TR, et al. Intravitreal ranibizumab and bevacizumab: a review of risk. Semin Ophthalmol. 2007;22(3):201-4. https://doi. org/10.1080/08820530701543024.

3. Sigford DK, Reddy S, Mollineaux C, et al. Global reported endophthalmitis risk following intravitreal injections of anti-VEGF: a literature review and analysis. Clin Ophthalmol. 2015;9:773-81. https:// doi.org/10.2147/opth.s77067.

4. Tsai JC, McClure CA, Ramos SE, et al. Compliance barriers in glaucoma: a systematic classification. J Glaucoma. 2003;12(5):393-8. https://doi.org/10. 1097/00061198-200310000-00001.

5. Pardue MT, Allen RS. Neuroprotective strategies for retinal disease. Prog Retin Eye Res. 2018;65:50-76. https://doi.org/10.1016/j.preteyeres.2018.02.002.

6. Cabrera FJ, Wang DC, Reddy K, et al. Challenges and opportunities for drug delivery to the posterior of the eye. Drug Discov Today. 2019;24(8):1679-84. https://doi.org/10.1016/j.drudis.2019.05.035.

7. Kim HM, Woo SJ. Ocular drug delivery to the retina: current innovations and future perspectives. Pharmaceutics. 2021. https://doi.org/10.3390/ pharmaceutics13010108.

8. Nayak K, Misra M. A review on recent drug delivery systems for posterior segment of eye. Biomed Pharmacother. 2018;107:1564-82. https://doi.org/ 10.1016/j.biopha.2018.08.138.

9. Jumelle C, Gholizadeh S, Annabi N, et al. Advances and limitations of drug delivery systems formulated as eye drops. J Control Release. 2020;321:1-22. https://doi.org/10.1016/j.jconrel.2020.01.057.

10. Tanito M, Hara K, Takai Y, et al. Topical dexamethasone-cyclodextrin microparticle eye drops for diabetic macular edema. Investig Ophthalmol Vis 
Sci. 2011;52(11):7944-8. https://doi.org/10.1167/ iovs.11-8178.

11. Kaur S, Yangzes S, Singh S, et al. Efficacy and safety of topical difluprednate in persistent diabetic macular edema. Int Ophthalmol. 2016;36(3):335-40. https://doi.org/10.1007/s10792-015-0121-3.

12. Lorenz K, Scheller Y, Bell K, et al. A prospective, randomised, placebo-controlled, double-masked, three-armed, multicentre phase II/III trial for the Study of a Topical Treatment of Ischaemic Central Retinal Vein Occlusion to Prevent Neovascular Glaucoma - the STRONG study: study protocol for a randomised controlled trial. Trials. 2017;18(1):128. https://doi.org/10.1186/s13063-017-1861-3.

13. Carpenter MA, Novack GD. FDA review times for new drugs in ophthalmology. Ocul Surf. 2020;18(4): 963-6. https://doi.org/10.1016/j.jtos.2020.08.003.

14. Williams GT, Haynes CJ, Fares M, et al. Advances in applied supramolecular technologies. Chem Soc Rev. 2021;50(4):2737-63.

15. Shikamura Y, Ohtori A, Tojo K. Drug penetration of the posterior eye tissues after topical instillation: in vivo and in silico simulation. Chem Pharm Bull. 2011;59(10):1263-7. https://doi.org/10.1248/cpb. 59.1263.

16. Rodrigues GA, Lutz D, Shen J, et al. Topical drug delivery to the posterior segment of the eye: addressing the challenge of preclinical to clinical translation. Pharm Res. 2018;35(12):245. https:// doi.org/10.1007/s11095-018-2519-x.

17. Ali MJ, Schicht M, Paulsen F. Morphology and morphometry of lacrimal drainage system in relation to bony landmarks in Caucasian adults: a cadaveric study. Int Ophthalmol. 2018;38(6): 2463-9. https://doi.org/10.1007/s10792-017-07536.

18. Webber WR, Jones DP, Wright P. Fluorophotometric measurements of tear turnover rate in normal healthy persons: evidence for a circadian rhythm. Eye. 1987;1(Pt 5):615-20. https://doi.org/10.1038/ eye.1987.95.

19. Shell JW. Pharmacokinetics of topically applied ophthalmic drugs. Surv Ophthalmol. 1982;26(4): 207-18. 6257(82)90081-9.

20. Gagliano C, Papa V, Amato R, et al. Measurement of the retention time of different ophthalmic formulations with ultrahigh-resolution optical coherence tomography. Curr Eye Res. 2018;43(4):499-502. https://doi.org/10.1080/02713683.2017.1418893.
21. Snibson GR, Greaves JL, Soper ND, et al. Ocular surface residence times of artificial tear solutions. Cornea. 1992;11(4):288-93. https://doi.org/10. 1097/00003226-199207000-00003.

22. Gaudana R, Ananthula HK, Parenky A, et al. Ocular drug delivery. AAPS J. 2010;12(3):348-60. https:// doi.org/10.1208/s12248-010-9183-3.

23. Fraunfelder FT, Meyer SM. Systemic side effects from ophthalmic timolol and their prevention. J Ocul Pharmacol. 1987;3(2):177-84. https://doi. org/10.1089/jop.1987.3.177.

24. Lim LT, Ah-Kee EY, Collins CE. Common eye drops and their implications for $\mathrm{pH}$ measurements in the management of chemical eye injuries. Int J Ophthalmol. 2014;7(6):1067-8. https://doi.org/10. 3980/j.issn.2222-3959.2014.06.29.

25. Zhu H, Chauhan A. Effect of viscosity on tear drainage and ocular residence time. Optom Vis Sci. 2008;85(8):715-25. https://doi.org/10.1097/OPX. Ob013e3181824dc4.

26. Sikora A, Oszczapowicz I, Tejchman B, et al. A method for the obtaining of increased viscosity eye drops containing amikacin. Acta Pol Pharm. 2005;62(1):31-7.

27. Patton TF, Robinson JR. Ocular evaluation of polyvinyl alcohol vehicle in rabbits. J Pharm Sci. 1975;64(8):1312-6. https://doi.org/10.1002/jps. 2600640811 .

28. Mikkelson TJ, Chrai SS, Robinson JR. Altered bioavailability of drugs in the eye due to drug-protein interaction. J Pharm Sci. 1973;62(10):1648-53. https://doi.org/10.1002/jps.2600621014.

29. Hornof M, Toropainen E, Urtti A. Cell culture models of the ocular barriers. Eur J Pharm Biopharm. 2005;60(2):207-25. https://doi.org/10. 1016/j.ejpb.2005.01.009.

30. Prausnitz MR, Noonan JS. Permeability of cornea, sclera, and conjunctiva: a literature analysis for drug delivery to the eye. J Pharm Sci. 1998;87(12): 1479-88. https://doi.org/10.1021/js9802594.

31. Noske W, Fromm M, Levarlet B, et al. Tight junctions of the human corneal endothelium: morphological and electrophysiological features. Ger J Ophthalmol. 1994;3(4-5):253-7.

32. Yi X, Wang Y, Yu FS. Corneal epithelial tight junctions and their response to lipopolysaccharide challenge. Investig Ophthalmol Vis Sci. 2000;41(13):4093-100.

33. Baba K, Tanaka Y, Kubota A, et al. A method for enhancing the ocular penetration of eye drops 
using nanoparticles of hydrolyzable dye. J Control Release. 2011;153(3):278-87. https://doi.org/10. 1016/j.jconrel.2011.04.019.

34. Huang HS, Schoenwald RD, Lach JL. Corneal penetration behavior of beta-blocking agents II: assessment of barrier contributions. J Pharm Sci. 1983;72(11):1272-9. https://doi.org/10.1002/jps. 2600721109.

35. Mun EA, Morrison PW, Williams AC, et al. On the barrier properties of the cornea: a microscopy study of the penetration of fluorescently labeled nanoparticles, polymers, and sodium fluorescein. Mol Pharm. 2014;11(10):3556-64. https://doi.org/ $10.1021 / \mathrm{mp} 500332 \mathrm{~m}$.

36. Liaw J, Rojanasakul Y, Robinson JR. The effect of drug charge type and charge density on corneal transport. Int J Pharm. 1992;88(1):111-24. https:// doi.org/10.1016/0378-5173(92)90308-O.

37. Eljarrat-Binstock E, Orucov F, Aldouby Y, et al. Charged nanoparticles delivery to the eye using hydrogel iontophoresis. J Control Release. 2008;126(2):156-61. https://doi.org/10.1016/j. jconrel.2007.11.016.

38. Battaglia L, Serpe L, Foglietta F, et al. Application of lipid nanoparticles to ocular drug delivery. Expert Opin Drug Deliv. 2016;13(12):1743-57. https://doi. org/10.1080/17425247.2016.1201059.

39. Geroski DH, Edelhauser HF. Transscleral drug delivery for posterior segment disease. Adv Drug Deliv Rev. 2001;52(1):37-48. https://doi.org/10. 1016/s0169-409x(01)00193-4.

40. Ramsay E, Del Amo EM, Toropainen E, et al. Corneal and conjunctival drug permeability: systematic comparison and pharmacokinetic impact in the eye. Eur J Pharm Sci. 2018;119:83-9. https://doi. org/10.1016/j.ejps.2018.03.034.

41. Goel M, Picciani RG, Lee RK, et al. Aqueous humor dynamics: a review. Open Ophthalmol J. 2010;4: 52-9. 1874364101004010052.

42. Tripathi RC, Millard CB, Tripathi BJ. Protein composition of human aqueous humor: SDS-PAGE analysis of surgical and post-mortem samples. Exp Eye Res. 1989;48(1):117-30. https://doi.org/10. 1016/0014-4835(89)90025-0.

43. Sit AJ, Nau CB, McLaren JW, et al. Circadian variation of aqueous dynamics in young healthy adults. Investig Ophthalmol Vis Sci. 2008;49(4):1473-9. https://doi.org/10.1167/iovs.07-1139.

44. Djebli N, Khier S, Griguer F, et al. Ocular drug distribution after topical administration: population pharmacokinetic model in rabbits. Eur J Drug Metab Pharmacokinet. 2017;42(1):59-68. https://doi.org/ 10.1007/s13318-016-0319-4.

45. Rimpelä AK, Reinisalo M, Hellinen L, et al. Implications of melanin binding in ocular drug delivery. Adv Drug Deliv Rev. 2018;126:23-43. https://doi. org/10.1016/j.addr.2017.12.008.

46. Tanaka H, Nitoh K, Atsuhiro A, et al. Measurement of volume of vitreous space during vitrectomy. Investig Ophthalmol Vis Sci. 2009;50(13): 3169-3169.

47. Silver DM, Geyer O. Pressure-volume relation for the living human eye. Curr Eye Res. 2000;20(2): $115-20$.

48. Lee B, Litt M, Buchsbaum G. Rheology of the vitreous body: part 3. Concentration of electrolytes, collagen and hyaluronic acid. Biorheology. 1994;31(4):339-51. https://doi.org/10.3233/bir1994-31404.

49. Silva AF, Alves MA, Oliveira MSN. Rheological behaviour of vitreous humour. Rheol Acta. 2017;56(4):377-86. s00397-017-0997-0.

https://doi.org/10.1007/

50. Xu Q, Boylan NJ, Suk JS, et al. Nanoparticle diffusion in, and microrheology of, the bovine vitreous ex vivo. J Control Release. 2013;167(1):76-84. https://doi.org/10.1016/j.jconrel.2013.01.018.

51. Narumi M, Nishitsuka K, Yamakawa $M$, et al. A survey of vitreous cell components performed using liquid-based cytology. Acta Ophthalmol. 2015;93(5):e386-390. https://doi.org/10.1111/aos. 12623.

52. Lazarus HS, Hageman GS. In situ characterization of the human hyalocyte. Arch Ophthalmol. 1994;112(10):1356-62. https://doi.org/10.1001/ archopht.1994.01090220106031.

53. Xu J, Heys JJ, Barocas VH, et al. Permeability and diffusion in vitreous humor: implications for drug delivery. Pharm Res. 2000;17(6):664-9. https://doi. org/10.1023/a:1007517912927.

54. Käsdorf BT, Arends F, Lieleg O. Diffusion regulation in the vitreous humor. Biophys J. 2015;109(10): 2171-81. https://doi.org/10.1016/j.bpj.2015.10. 002.

55. Dias CS, Mitra AK. Vitreal elimination kinetics of large molecular weight FITC-labeled dextrans in albino rabbits using a novel microsampling technique. J Pharm Sci. 2000;89(5):572-8. https://doi. org/10.1002/(sici)1520-6017(200005)89:5\%3c572:: aid-jps2\%3e3.0.co;2-p. 
56. Tojo K, Nakagawa K, Morita Y, et al. A pharmacokinetic model of intravitreal delivery of ganciclovir. Eur J Pharm Biopharm. 1999;47(2):99-104. https://doi.org/10.1016/s0939-6411(98)00073-3.

57. Varela-Fernández R, Díaz-Tomé V, Luaces-Rodríguez A, et al. Drug delivery to the posterior segment of the eye: biopharmaceutic and pharmacokinetic considerations. Pharmaceutics. 2020. https://doi. org/10.3390/pharmaceutics12030269.

58. Gaudreault J, Fei D, Rusit J, et al. Preclinical pharmacokinetics of ranibizumab (rhuFabV2) after a single intravitreal administration. Investig Ophthalmol Vis Sci. 2005;46(2):726-33. https://doi.org/ 10.1167/iovs.04-0601.

59. Caruso A, Füth M, Alvarez-Sánchez R, et al. Ocular half-life of intravitreal biologics in humans and other species: meta-analysis and model-based prediction. Mol Pharm. 2020;17(2):695-709. https:// doi.org/10.1021/acs.molpharmaceut.9b01191.

60. Morlet N, Young S, Naidoo D, et al. High dose intravitreal ganciclovir injection provides a prolonged therapeutic intraocular concentration. $\mathrm{Br} \mathrm{J}$ Ophthalmol. 1996;80(3):214-6. https://doi.org/10. 1136/bjo.80.3.214.

61. van Deemter M, Kuijer R, Harm Pas H, et al. Trypsinmediated enzymatic degradation of type II collagen in the human vitreous. Mol Vis. 2013;19:1591-9.

62. Dias CS, Anand BS, Mitra AK. Effect of mono- and di-acylation on the ocular disposition of ganciclovir: physicochemical properties, ocular bioreversion, and antiviral activity of short chain ester prodrugs. J Pharm Sci. 2002;91(3):660-8. https:// doi.org/10.1002/jps.10072.

63. Gilger BC, Reeves KA, Salmon JH. Ocular parameters related to drug delivery in the canine and equine eye: aqueous and vitreous humor volume and scleral surface area and thickness. Vet Ophthalmol. 2005;8(4):265-9. https://doi.org/10.1111/j.14635224.2005.00401.x.

64. Meng T, Kulkarni V, Simmers R, et al. Therapeutic implications of nanomedicine for ocular drug delivery. Drug Discov Today. 2019;24(8):1524-38. https://doi.org/10.1016/j.drudis.2019.05.006.

65. Bobo D, Robinson KJ, Islam J, et al. Nanoparticlebased medicines: a review of FDA-approved materials and clinical trials to date. Pharm Res. 2016;33(10):2373-87. https://doi.org/10.1007/ s11095-016-1958-5.

66. Patel A, Cholkar K, Agrahari V, et al. Ocular drug delivery systems: an overview. World J Pharmacol. 2013;2(2):47-64. https://doi.org/10.5497/wjp.v2.i2. 47.
67. Durak S, Esmaeili Rad M, Alp Yetisgin A, et al. Niosomal drug delivery systems for ocular diseaserecent advances and future prospects. Nanomaterials. 2020. https://doi.org/10.3390/nano10061191.

68. Bartelds R, Nematollahi MH, Pols T, et al. Niosomes, an alternative for liposomal delivery. PLoS ONE. 2018;13(4): e0194179. https://doi.org/10.1371/ journal.pone.0194179.

69. Chang HI, Yeh MK. Clinical development of liposome-based drugs: formulation, characterization, and therapeutic efficacy. Int J Nanomed. 2012;7: 49-60. https://doi.org/10.2147/ijn.s26766.

70. Cheng T, Li J, Cheng Y, et al. Triamcinolone acetonide-chitosan coated liposomes efficiently treated retinal edema as eye drops. Exp Eye Res. 2019;188: 107805. https://doi.org/10.1016/j.exer.2019. 107805 .

71. Davis BM, Normando EM, Guo L, et al. Topical delivery of Avastin to the posterior segment of the eye in vivo using annexin A5-associated liposomes. Small. 2014;10(8):1575-84. https://doi.org/10. 1002/smll.201303433.

72. Lu FS, Nielsen NS, Timm-Heinrich M, et al. Oxidative stability of marine phospholipids in the liposomal form and their applications. Lipids. 2011;46(1):3-23. https://doi.org/10.1007/s11745$010-3496-y$.

73. Khalil RM, Abdelbary GA, Basha $M$, et al. Enhancement of lomefloxacin $\mathrm{Hcl}$ ocular efficacy via niosomal encapsulation: in vitro characterization and in vivo evaluation. J Liposome Res. 2017;27(4):312-23. https://doi.org/10.1080/ 08982104.2016 .1191022 .

74. Gugleva V, Titeva S, Rangelov S, et al. Design and in vitro evaluation of doxycycline hyclate niosomes as a potential ocular delivery system. Int J Pharm. 2019;567: 118431. https://doi.org/10.1016/j. ijpharm.2019.06.022.

75. Jain N, Verma A, Jain N. Formulation and investigation of pilocarpine hydrochloride niosomal gels for the treatment of glaucoma: intraocular pressure measurement in white albino rabbits. Drug Deliv. 2020;27(1):888-99. https://doi.org/10.1080/ 10717544.2020 .1775726 .

76. Barza M, Stuart M, Szoka F Jr. Effect of size and lipid composition on the pharmacokinetics of intravitreal liposomes. Investig Ophthalmol Vis Sci. 1987;28(5):893-900.

77. Danaei M, Dehghankhold M, Ataei S, et al. Impact of particle size and polydispersity index on the clinical applications of lipidic nanocarrier systems. 
Pharmaceutics. 2018. https://doi.org/10.3390/ pharmaceutics10020057.

78. Maiti S, Paul S, Mondol R, et al. Nanovesicular formulation of brimonidine tartrate for the management of glaucoma: in vitro and in vivo evaluation. AAPS PharmSciTech. 2011;12(2):755-63. https:// doi.org/10.1208/s12249-011-9643-9.

79. Dézsi L, Fülöp T, Mészáros T, et al. Features of complement activation-related pseudoallergy to liposomes with different surface charge and PEGylation: comparison of the porcine and rat responses. J Control Release. 2014;195:2-10. https://doi.org/ 10.1016/j.jconrel.2014.08.009.

80. Szebeni J, Bedocs P, Rozsnyay Z, et al. Liposomeinduced complement activation and related cardiopulmonary distress in pigs: factors promoting reactogenicity of Doxil and Am Bisome. Nanomedicine. 2012;8(2):176-84. https://doi.org/10.1016/j. nano.2011.06.003.

81. Szebeni J. Complement activation-related pseudoallergy: a stress reaction in blood triggered by nanomedicines and biologicals. Mol Immunol. 2014;61(2):163-73. molimm.2014.06.038.

82. Chanan-Khan A, Szebeni J, Savay S, et al. Complement activation following first exposure to pegylated liposomal doxorubicin (Doxil): possible role in hypersensitivity reactions. Ann Oncol. 2003;14(9): 1430-7. https://doi.org/10.1093/annonc/mdg374.

83. Bochot A, Fattal E, Boutet $\mathrm{V}$, et al. Intravitreal delivery of oligonucleotides by sterically stabilized liposomes. Investig Ophthalmol Vis Sci. 2002;43(1): 253-9.

84. Lajavardi L, Bochot A, Camelo S, et al. Downregulation of endotoxin-induced uveitis by intravitreal injection of vasoactive intestinal peptide encapsulated in liposomes. Investig Ophthalmol Vis Sci. 2007;48(7):3230-8. https://doi.org/10.1167/iovs. 06-1305.

85. Bochot A, Fattal E. Liposomes for intravitreal drug delivery: a state of the art. J Control Release. 2012;161(2):628-34. https://doi.org/10.1016/j. jconrel.2012.01.019.

86. Cholkar K, Patel A, Vadlapudi AD, et al. Novel nanomicellar formulation approaches for anterior and posterior segment ocular drug delivery. Recent Pat Nanomed. 2012;2(2):82-95. https://doi.org/10. $2174 / 1877912311202020082$.

87. Pepić I, Lovrić J, Filipović-Grčić J. How do polymeric micelles cross epithelial barriers? Eur J Pharm Sci. 2013;50(1):42-55. https://doi.org/10.1016/j.ejps. 2013.04.012.
88. Vellonen KS, Hellinen L, Mannermaa E, et al. Expression, activity and pharmacokinetic impact of ocular transporters. Adv Drug Deliv Rev. 2018;126: 3-22. https://doi.org/10.1016/j.addr.2017.12.009.

89. Di Prima G, Saladino S, Bongiovì F, et al. Novel inulin-based mucoadhesive micelles loaded with corticosteroids as potential transcorneal permeation enhancers. Eur J Pharm Biopharm. 2017;117: 385-99. https://doi.org/10.1016/j.ejpb.2017.05. 005.

90. Grimaudo MA, Pescina S, Padula C, et al. Topical application of polymeric nanomicelles in ophthalmology: a review on research efforts for the noninvasive delivery of ocular therapeutics. Expert Opin Drug Deliv. 2019;16(4):397-413. https://doi. org/10.1080/17425247.2019.1597848.

91. Weng YH, Ma XW, Che J, et al. Nanomicelle-assisted targeted ocular delivery with enhanced antiinflammatory efficacy in vivo. Adv Sci. 2018;5(1): 1700455. https://doi.org/10.1002/advs.201700455.

92. Cholkar K, Gilger BC, Mitra AK. Topical, aqueous, clear cyclosporine formulation design for anterior and posterior ocular delivery. Transl Vis Sci Technol. 2015;4(3):1. https://doi.org/10.1167/tvst.4.3.1.

93. Zhang Y, Ren T, Gou J, et al. Strategies for improving the payload of small molecular drugs in polymeric micelles. J Control Release. 2017;261:352-66. https://doi.org/10.1016/j.jconrel.2017.01.047.

94. Mandal A, Gote V, Pal D, et al. Ocular pharmacokinetics of a topical ophthalmic nanomicellar solution of cyclosporine (Cequa $\left.{ }^{\circledR}\right)$ for dry eye disease. Pharm Res. 2019;36(2):36. https://doi.org/10. 1007/s11095-018-2556-5.

95. Kondiah PPD, Choonara YE, Kondiah PJ, et al. 17 Nanocomposites for therapeutic application in multiple sclerosis. In: Inamuddin, Asiri AM, Mohammad A, editors., et al., Applications of nanocomposite materials in drug delivery. Woodhead; 2018. p. 391-408.

96. Talevi A, Gantner ME, Ruiz ME. Applications of nanosystems to anticancer drug therapy (Part I. Nanogels, nanospheres, nanocapsules). Recent Pat Anticancer Drug Discov. 2014;9(1):83-98. https:// doi.org/10.2174/1574891x113089990035.

97. Janagam DR, Wu L, Lowe TL. Nanoparticles for drug delivery to the anterior segment of the eye. Adv Drug Deliv Rev. 2017;122:31-64. https://doi.org/10. 1016/j.addr.2017.04.001.

98. Guterres SS, Alves MP, Pohlmann AR. Polymeric nanoparticles, nanospheres and nanocapsules, for cutaneous applications. Drug Target Insights. 2007;2:147-57. 
99. Kuhn DA, Vanhecke D, Michen B, et al. Different endocytotic uptake mechanisms for nanoparticles in epithelial cells and macrophages. Beilstein J Nanotechnol. 2014;5:1625-36. https://doi.org/10. 3762/bjnano.5.174.

100. Kou L, Sun J, Zhai Y, et al. The endocytosis and intracellular fate of nanomedicines: implication for rational design. Asian J Pharm Sci. 2013;8(1):1-10.

101. Ludwig A. The use of mucoadhesive polymers in ocular drug delivery. Adv Drug Deliv Rev. 2005;57(11):1595-639. https://doi.org/10.1016/j. addr.2005.07.005.

102. Bessone CDV, Martinez SM, Luna JD, et al. Neuroprotective effect of melatonin loaded in ethylcellulose nanoparticles applied topically in a retinal degeneration model in rabbits. Exp Eye Res. 2020;200: 108222. https://doi.org/10.1016/j.exer. 2020.108222 .

103. Fresta M, Fontana G, Bucolo C, et al. Ocular tolerability and in vivo bioavailability of poly(ethylene glycol) (PEG)-coated polyethyl-2-cyanoacrylate nanosphere-encapsulated acyclovir. J Pharm Sci. 2001;90(3):288-97. https://doi.org/10.1002/15206017(200103)90:3\%3c288::aid-jps4\%3e3.0.co;2-5.

104. Halasz K, Kelly SJ, Iqbal MT, et al. Micro/nanoparticle delivery systems for ocular diseases. Assay Drug Dev Technol. 2019;17(4):152-66. https://doi.org/ 10.1089/adt.2018.911.

105. Prow TW, Bhutto I, Kim SY, et al. Ocular nanoparticle toxicity and transfection of the retina and retinal pigment epithelium. Nanomedicine. 2008;4(4):340-9. https://doi.org/10.1016/j.nano. 2008.06.003.

106. Freitas LGA, Isaac DLC, Lima EM, et al. Retinal changes in rabbit after intravitreal injection of sunitinib encapsulated into solid lipid nanoparticles and polymeric nanocapsules. Arq Bras Oftalmol. 2018;81(5):408-13. https://doi.org/10.5935/ 0004-2749.20180079.

107. Thackaberry EA, Farman C, Zhong F, et al. Evaluation of the toxicity of intravitreally injected PLGA microspheres and rods in monkeys and rabbits: effects of depot size on inflammatory response. Investig Ophthalmol Vis Sci. 2017;58(10):4274-85. https://doi.org/10.1167/iovs.16-21334.

108. Hirao A, Yoo H-S. Dendrimer-like star-branched polymers: novel structurally well-defined hyperbranched polymers. Polym J. 2011;43(1):2-17.

109. Tai L, Liu C, Jiang K, et al. A novel penetratinmodified complex for noninvasive intraocular delivery of antisense oligonucleotides. Int J Pharm.
2017;529(1-2):347-56. https://doi.org/10.1016/j. ijpharm.2017.06.090.

110. Hudde T, Rayner SA, Comer RM, et al. Activated polyamidoamine dendrimers, a non-viral vector for gene transfer to the corneal endothelium. Gene Ther. 1999;6(5):939-43. https://doi.org/10.1038/sj. gt. 3300886 .

111. Bravo-Osuna I, Noiray M, Briand E, et al. Interfacial interaction between transmembrane ocular mucins and adhesive polymers and dendrimers analyzed by surface plasmon resonance. Pharm Res. 2012;29(8): 2329-40. https://doi.org/10.1007/s11095-012-07611.

112. Dąbkowska M, Rogińska D, Kłos P, et al. Electrostatic complex of neurotrophin 4 with dendrimer nanoparticles: controlled release of protein in vitro and in vivo. Int $\mathrm{J}$ Nanomed. 2019;14:6117-31. https://doi.org/10.2147/ijn.s210140.

113. Kambhampati SP, Clunies-Ross AJ, Bhutto I, et al. Systemic and intravitreal delivery of dendrimers to activated microglia/macrophage in ischemia/reperfusion mouse retina. Investig Ophthalmol Vis Sci. 2015;56(8):4413-24. https://doi.org/10.1167/iovs. 14-16250.

114. Guo Y, Johnson MA, Mehrabian Z, et al. Dendrimers target the ischemic lesion in rodent and primate models of nonarteritic anterior ischemic optic neuropathy. PLoS ONE. 2016;11(4): e0154437. https://doi.org/10.1371/journal.pone.0154437.

115. Soiberman U, Kambhampati SP, Wu T, et al. Subconjunctival injectable dendrimer-dexamethasone gel for the treatment of corneal inflammation. Biomaterials. 2017;125:38-53. https://doi.org/10. 1016/j.biomaterials.2017.02.016.

116. Yang X, Wang L, Li L, et al. A novel dendrimerbased complex co-modified with cyclic RGD hexapeptide and penetratin for noninvasive targeting and penetration of the ocular posterior segment. Drug Deliv. 2019;26(1):989-1001. https:// doi.org/10.1080/10717544.2019.1667455.

117. Malik N, Wiwattanapatapee R, Klopsch R, et al. Dendrimers: relationship between structure and biocompatibility in vitro, and preliminary studies on the biodistribution of 125I-labelled polyamidoamine dendrimers in vivo. J Control Release. 2000;65(1-2):133-48. https://doi.org/10.1016/ s0168-3659(99)00246-1.

118. Nagpal K, Kumar P, Mohan A, et al. Dendrimers for therapeutic delivery: compositions, characterizations, and current status. Crit Rev Ther Drug Carr Syst. 2019;36(4):277-304. https://doi.org/10.1615/ CritRevTherDrugCarrierSyst.2018025749. 
119. Chen HT, Neerman MF, Parrish AR, et al. Cytotoxicity, hemolysis, and acute in vivo toxicity of dendrimers based on melamine, candidate vehicles for drug delivery. J Am Chem Soc. 2004;126(32): 10044-8. https://doi.org/10.1021/ja048548j.

120. Grinstaff MW. Designing hydrogel adhesives for corneal wound repair. Biomaterials. 2007;28(35): 5205-14. https://doi.org/10.1016/j.biomaterials. 2007.08.041.

121. Youssef AAA, Cai C, Dudhipala N, et al. Design of topical ocular ciprofloxacin nanoemulsion for the management of bacterial keratitis. Pharmaceuticals. 2021. https://doi.org/10.3390/ph14030210.

122. Jian HJ, Wu RS, Lin TY, et al. Super-cationic carbon quantum dots synthesized from spermidine as an eye drop formulation for topical treatment of bacterial keratitis. ACS Nano. 2017;11(7):6703-16. https://doi.org/10.1021/acsnano.7b01023.

123. Nair AB, Shah J, Al-Dhubiab BE, et al. Clarithromycin solid lipid nanoparticles for topical ocular therapy: optimization, evaluation and in vivo studies. Pharmaceutics. 2021. https://doi. org/10.3390/pharmaceutics13040523.

124. Kouchak M. In situ gelling systems for drug delivery. Jundishapur J Nat Pharm Prod. 2014;9(3): e20126. https://doi.org/10.17795/jjnpp-20126.

125. Wu Y, Liu Y, Li X, et al. Research progress of in-situ gelling ophthalmic drug delivery system. Asian J Pharm Sci. 2019;14(1):1-15. https://doi.org/10. 1016/j.ajps.2018.04.008.

126. Ako-Adounvo AM, Nagarwal RC, Oliveira L, et al. Recent patents on ophthalmic nanoformulations and therapeutic implications. Recent Pat Drug Deliv Formul. 2014;8(3):193-201. https://doi.org/10. 2174/1872211308666140926112000.

127. Başaran B, Bozkir A. Thermosensitive and $\mathrm{pH}$ induced in situ ophthalmic gelling system for ciprofloxacin hydrochloride: hydroxypropyl-betacyclodextrin complex. Acta Pol Pharm. 2012;69(6): 1137-47.

128. Deguchi S, Ogata F, Yamaguchi $M$, et al. In situ gel incorporating disulfiram nanoparticles rescues the retinal dysfunction via ATP collapse in Otsuka Long-Evans Tokushima fatty rats. Cells. 2020. https://doi.org/10.3390/cells9102171.

129. Yu J, Xu X, Yao F, et al. In situ covalently crosslinked PEG hydrogel for ocular drug delivery applications. Int J Pharm. 2014;470(1-2):151-7. https://doi.org/10.1016/j.ijpharm.2014.04.053.

130. Al Khateb K, Ozhmukhametova EK, Mussin MN, et al. In situ gelling systems based on Pluronic F127/
Pluronic F68 formulations for ocular drug delivery. Int J Pharm. 2016;502(1-2):70-9. https://doi.org/ 10.1016/j.ijpharm.2016.02.027.

131. Janga KY, Tatke A, Balguri SP, et al. Ion-sensitive in situ hydrogels of natamycin bilosomes for enhanced and prolonged ocular pharmacotherapy: in vitro permeability, cytotoxicity and in vivo evaluation. Artif Cells Nanomed Biotechnol. 2018;46(sup1):1039-50. https://doi.org/10.1080/ 21691401.2018.1443117.

132. Fernández-Ferreiro A, González Barcia M, Gil-Martínez $\mathrm{M}$, et al. In vitro and in vivo ocular safety and eye surface permanence determination by direct and magnetic resonance imaging of ion-sensitive hydrogels based on gellan gum and kappa-carrageenan. Eur J Pharm Biopharm. 2015;94:342-51. https://doi.org/10.1016/j.ejpb.2015.06.003.

133. Huang D, Chen YS, Rupenthal ID. Overcoming ocular drug delivery barriers through the use of physical forces. Adv Drug Deliv Rev. 2018;126: 96-112. https://doi.org/10.1016/j.addr.2017.09. 008 .

134. Gratieri T, Santer V, Kalia YN. Basic principles and current status of transcorneal and transscleral iontophoresis. Expert Opin Drug Deliv. 2017;14(9): 1091-102. https://doi.org/10.1080/17425247.2017. 1266334.

135. Li SK, Hao J. Transscleral passive and iontophoretic transport: theory and analysis. Expert Opin Drug Deliv. 2018;15(3):283-99. https://doi.org/10.1080/ 17425247.2018.1406918.

136. Abla N, Naik A, Guy RH, et al. Effect of charge and molecular weight on transdermal peptide delivery by iontophoresis. Pharm Res. 2005;22(12):2069-78. https://doi.org/10.1007/s11095-005-8110-2.

137. Pikal MJ. The role of electroosmotic flow in transdermal iontophoresis. Adv Drug Deliv Rev. 2001;46(1-3):281-305. https://doi.org/10.1016/ s0169-409x(00)00138-1.

138. Hughes L, Maurice DM. A fresh look at iontophoresis. Arch Ophthalmol. 1984;102(12): 1825-9. https://doi.org/10.1001/archopht.1984. 01040031483028.

139. Perez VL, Wirostko B, Korenfeld M, et al. Ophthalmic drug delivery using iontophoresis: recent clinical applications. J Ocul Pharmacol Ther. 2020;36(2):75-87. https://doi.org/10.1089/jop. 2019.0034 .

140. O'Neil EC, Huang J, Suhler EB, et al. Iontophoretic delivery of dexamethasone phosphate for non-infectious, non-necrotising anterior scleritis, dosefinding clinical trial. Br J Ophthalmol. 2018;102(8): 
1011-3. https://doi.org/10.1136/bjophthalmol2017-311610.

141. Parkinson TM, Ferguson E, Febbraro S, et al. Tolerance of ocular iontophoresis in healthy volunteers. J Ocul Pharmacol Ther. 2003;19(2):145-51. https:// doi.org/10.1089/108076803321637672.

142. Molokhia S, Papangkorn K, Butler C, et al. Transscleral iontophoresis for noninvasive ocular drug delivery of macromolecules. J Ocul Pharmacol Ther. 2020;36(4):247-56. https://doi.org/10.1089/jop. 2019.0081 .

143. Ueda H, Mutoh M, Seki T, et al. Acoustic cavitation as an enhancing mechanism of low-frequency sonophoresis for transdermal drug delivery. Biol Pharm Bull. 2009;32(5):916-20. https://doi.org/10. 1248/bpb.32.916.

144. Fellinger K, Schmid J. Klinik und Therapie des chronischen Gelenkrheumatismus. Berlin: Verlag für Medizinische Wissenschaften; 1954.

145. Huang D, Wang L, Dong Y, et al. A novel technology using transscleral ultrasound to deliver protein loaded nanoparticles. Eur J Pharm Biopharm. 2014;88(1):104-15. https://doi.org/10.1016/j.ejpb. 2014.04.011.

146. Chau Y, Suen WL, Tse HY, et al. Ultrasound-enhanced penetration through sclera depends on frequency of sonication and size of macromolecules. Eur J Pharm Sci. 2017;100:273-9. https://doi.org/10. 1016/j.ejps.2017.01.016.

147. Gratieri T, Gelfuso GM, Thomazini JA, et al. Excised porcine cornea integrity evaluation in an in vitro model of iontophoretic ocular research. Ophthalmic Res. 2010;43(4):208-16. https://doi.org/10. $1159 / 000274494$.

148. Molokhia SA, Jeong EK, Higuchi WI, et al. Examination of barriers and barrier alteration in transscleral iontophoresis. J Pharm Sci. 2008;97(2): 831-44. https://doi.org/10.1002/jps.21003.

149. Wu YH, Chen WS, Luh JJ, et al. Thermal effect of sonophoresis for accelerating the analgesic effect of local anesthetics on rat tail nerve. Conf Proc IEEE Eng Med Biol Soc. 2008;2008:2504-7. https://doi. org/10.1109/iembs.2008.4649709.

150. Song HB, Lee KJ, Seo IH, et al. Impact insertion of transfer-molded microneedle for localized and minimally invasive ocular drug delivery. J Control Release. 2015;209:272-9. https://doi.org/10.1016/j. jconrel.2015.04.041.

151. Thakur RR, Tekko IA, Al-Shammari F, et al. Rapidly dissolving polymeric microneedles for minimally invasive intraocular drug delivery. Drug Deliv
Transl Res. 2016;6(6):800-15. https://doi.org/10. 1007/s13346-016-0332-9.

152. Gu X, Reagan AM, McClellan ME, et al. Caveolins and caveolae in ocular physiology and pathophysiology. Prog Retin Eye Res. 2017;56:84-106. https:// doi.org/10.1016/j.preteyeres.2016.09.005.

153. Nelemans LC, Gurevich L. Drug delivery with polymeric nanocarriers-cellular uptake mechanisms. Materials. 2020. https://doi.org/10.3390/ ma13020366.

154. Martens TF, Remaut K, Deschout H, et al. Coating nanocarriers with hyaluronic acid facilitates intravitreal drug delivery for retinal gene therapy. J Control Release. 2015;202:83-92. https://doi.org/ 10.1016/j.jconrel.2015.01.030.

155. Coutinho FP, Green CR, Rupenthal ID. Intracellular oligonucleotide delivery using the cell penetrating peptide Xentry. Sci Rep. 2018;8(1):11256. https:// doi.org/10.1038/s41598-018-29556-7.

156. Guidotti G, Brambilla L, Rossi D. Cell-penetrating peptides: from basic research to clinics. Trends Pharmacol Sci. 2017;38(4):406-24. https://doi.org/ 10.1016/j.tips.2017.01.003.

157. Wang Y, Lin H, Lin S, et al. Cell-penetrating peptide TAT-mediated delivery of acidic FGF to retina and protection against ischemia-reperfusion injury in rats. J Cell Mol Med. 2010;14(7):1998-2005. https:// doi.org/10.1111/j.1582-4934.2009.00786.x.

158. de Cogan F, Hill LJ, Lynch A, et al. Topical delivery of anti-VEGF drugs to the ocular posterior segment using cell-penetrating peptides. Investig Ophthalmol Vis Sci. 2017;58(5):2578-90. https://doi.org/10. 1167/iovs.16-20072.

159. Johnson LN, Cashman SM, Read SP, et al. Cell penetrating peptide POD mediates delivery of recombinant proteins to retina, cornea and skin. Vis Res. 2010;50(7):686-97. https://doi.org/10.1016/j. visres.2009.08.028.

160. Pescina S, Ostacolo C, Gomez-Monterrey IM, et al. Cell penetrating peptides in ocular drug delivery: state of the art. J Control Release. 2018;284:84-102. https://doi.org/10.1016/j.jconrel.2018.06.023.

161. Willms E, Cabañas C, Mäger I, et al. Extracellular vesicle heterogeneity: subpopulations, isolation techniques, and diverse functions in cancer progression. Front Immunol. 2018;9:738. https://doi. org/10.3389/fimmu.2018.00738.

162. Raposo G, Stoorvogel W. Extracellular vesicles: exosomes, microvesicles, and friends. J Cell Biol. 2013;200(4):373-83. https://doi.org/10.1083/jcb. 201211138. 
163. Doyle LM, Wang MZ. Overview of extracellular vesicles, their origin, composition, purpose, and methods for exosome isolation and analysis. Cells. 2019. https://doi.org/10.3390/cells8070727.

164. Latifkar A, Hur YH, Sanchez JC, et al. New insights into extracellular vesicle biogenesis and function. J Cell Sci. 2019. https://doi.org/10.1242/jcs.222406.

165. Li N, Zhao L, Wei Y, et al. Recent advances of exosomes in immune-mediated eye diseases. Stem Cell Res Ther. 2019;10(1):278. https://doi.org/10.1186/ s13287-019-1372-0.

166. Huang Y, Li R, Ye S, et al. Recent advances in the use of exosomes in Sjögren's syndrome. Front Immunol. 2020;11:1509. https://doi.org/10.3389/fimmu. 2020.01509 .

167. Bai L, Shao H, Wang H, et al. Effects of mesenchymal stem cell-derived exosomes on experimental autoimmune uveitis. Sci Rep. 2017;7(1):4323. https://doi.org/10.1038/s41598-017-04559-y.

168. Han KY, Tran JA, Chang JH, et al. Potential role of corneal epithelial cell-derived exosomes in corneal wound healing and neovascularization. Sci Rep. 2017;7:40548. https://doi.org/10.1038/srep40548.

169. Yu C, Chen $\mathrm{P}, \mathrm{Xu}$ J, et al. hADSCs derived extracellular vesicles inhibit NLRP3inflammasome activation and dry eye. Sci Rep. 2020;10(1):14521. https://doi.org/10.1038/s41598-020-71337-8.

170. Elsharkasy OM, Nordin JZ, Hagey DW, et al. Extracellular vesicles as drug delivery systems: why and how? Adv Drug Deliv Rev. 2020. https://doi.org/10. 1016/j.addr.2020.04.004.

171. Wassmer SJ, Carvalho LS, György B, et al. Exosomeassociated AAV2 vector mediates robust gene delivery into the murine retina upon intravitreal injection. Sci Rep. 2017;7:45329. https://doi.org/10. 1038/srep45329.

172. Hajrasouliha AR, Jiang G, Lu Q, et al. Exosomes from retinal astrocytes contain antiangiogenic components that inhibit laser-induced choroidal neovascularization. J Biol Chem. 2013;288(39): 28058-67. https://doi.org/10.1074/jbc.M113. 470765.

173. van der Merwe Y, Steketee MB. Extracellular vesicles: biomarkers, therapeutics, and vehicles in the visual system. Curr Ophthalmol Rep. 2017;5(4): 276-82. https://doi.org/10.1007/s40135-017-01530.

174. Tabak S, Schreiber-Avissar S, Beit-Yannai E. Influence of anti-glaucoma drugs on uptake of extracellular vesicles by trabecular meshwork cells. Int J
Nanomed. 2021;16:1067-81. https://doi.org/10. 2147/IJN.S283164.

175. Armstrong JPK, Stevens MM. Strategic design of extracellular vesicle drug delivery systems. Adv Drug Deliv Rev. 2018;130:12-6. https://doi.org/10. 1016/j.addr.2018.06.017.

176. Saleh AF, Lázaro-Ibáñez E, Forsgard MA, et al. Extracellular vesicles induce minimal hepatotoxicity and immunogenicity. Nanoscale. 2019;11(14): 6990-7001. https://doi.org/10.1039/c8nr08720b.

177. Escudier B, Dorval T, Chaput N, et al. Vaccination of metastatic melanoma patients with autologous dendritic cell (DC) derived-exosomes: results of thefirst phase I clinical trial. J Transl Med. 2005;3(1):10. https://doi.org/10.1186/1479-5876-310.

178. Dai S, Wei D, Wu Z, et al. Phase I clinical trial of autologous ascites-derived exosomes combined with GM-CSF for colorectal cancer. Mol Ther. 2008;16(4):782-90. https://doi.org/10.1038/mt. 2008.1 .

179. Besse B, Charrier M, Lapierre V, et al. Dendritic cellderived exosomes as maintenance immunotherapy after first line chemotherapy in NSCLC. Oncoimmunology. 2016;5(4): e1071008. https://doi.org/10. 1080/2162402x.2015.1071008.

180. Guo M, Wu F, Hu G, et al. Autologous tumor cellderived microparticle-based targeted chemotherapy in lung cancer patients with malignant pleural effusion. Sci Transl Med. 2019. https://doi.org/10. 1126/scitranslmed.aat5690.

181. Ingato D, Lee JU, Sim SJ, et al. Good things come in small packages: overcoming challenges to harness extracellular vesicles for therapeutic delivery. J Control Release. 2016;241:174-85. https://doi.org/ 10.1016/j.jconrel.2016.09.016.

182. Andriolo G, Provasi E, Lo Cicero V, et al. Exosomes from human cardiac progenitor cells for therapeutic applications: development of a GMP-grade manufacturing method. Front Physiol. 2018;9:1169. https://doi.org/10.3389/fphys.2018.01169.

183. Heath N, Grant L, De Oliveira TM, et al. Rapid isolation and enrichment of extracellular vesicle preparations using anion exchange chromatography. Sci Rep. 2018;8(1):5730. https://doi.org/10. 1038/s41598-018-24163-y.

184. Horita S, Watanabe M, Katagiri M, et al. Species differences in ocular pharmacokinetics and pharmacological activities of regorafenib and pazopanib eye-drops among rats, rabbits and monkeys. Pharmacol Res Perspect. 2019;7(6): e00545. https://doi. org/10.1002/prp2.545. 
185. Joussen AM, Wolf S, Kaiser PK, et al. The developing regorafenib eye drops for neovascular age-related macular degeneration (DREAM) study: an open-label phase II trial. Br J Clin Pharmacol. 2019;85(2): 347-55. https://doi.org/10.1111/bcp.13794.

186. Yafai Y, Yang XM, Niemeyer M, et al. Anti-angiogenic effects of the receptor tyrosine kinase inhibitor, pazopanib, on choroidal neovascularization in rats. Eur J Pharmacol. 2011;666(1-3):12-8. https://doi.org/10.1016/j.ejphar.2011.05.016.

187. Takahashi K, Saishin Y, Saishin Y, et al. Suppression and regression of choroidal neovascularization by the multitargeted kinase inhibitor pazopanib. Arch Ophthalmol. 2009;127(4):494-9. https://doi.org/ 10.1001/archophthalmol.2009.27.

188. Csaky KG, Dugel PU, Pierce AJ, et al. Clinical evaluation of pazopanib eye drops versus ranibizumab intravitreal injections in subjects with neovascular age-related macular degeneration. Ophthalmology. 2015;122(3):579-88. https://doi.org/10.1016/j. ophtha.2014.09.036.

189. Wroblewski JJ, Hu AY. Topical squalamine $0.2 \%$ and intravitreal ranibizumab $0.5 \mathrm{mg}$ as combination therapy for macular edema due to branch and central retinal vein occlusion: an open-label, randomized study. Ophthalmic Surg Lasers Imaging Retin. 2016;47(10):914-23. https://doi.org/10.3928/ 23258160-20161004-04.

190. Tanito M, Li F, Anderson RE. Protection of retinal pigment epithelium by OT-551 and its metabolite TEMPOL-H against light-induced damage in rats. Exp Eye Res. 2010;91(1):111-4. https://doi.org/10. 1016/j.exer.2010.04.012.

191. Wong WT, Kam W, Cunningham D, et al. Treatment of geographic atrophy by the topical administration of OT-551: results of a phase II clinical trial. Investig Ophthalmol Vis Sci. 2010;51(12): 6131-9. https://doi.org/10.1167/iovs.10-5637.

192. Shah M, Cabrera-Ghayouri S, Christie LA, et al. Translational preclinical pharmacologic disease models for ophthalmic drug development. Pharm Res. 2019;36(4):58. https://doi.org/10.1007/s11095019-2588-5.

193. Singh R, Wurzelmann JI, Ye L, et al. Clinical evaluation of pazopanib eye drops in healthy subjects and in subjects with neovascular age-related macular degeneration. Retina. 2014;34(9):1787-95. https://doi.org/10.1097/iae.0000000000000179.

194. Ma X, Liu J, Zhu W, et al. 3D bioprinting of functional tissue models for personalized drug screening and in vitro disease modeling. Adv Drug Deliv Rev. 2018;132:235-51. https://doi.org/10.1016/j.addr. 2018.06.011.
195. Derr K, Zou J, Luo K, et al. Fully three-dimensional bioprinted skin equivalent constructs with validated morphology and barrier function. Tissue Eng Part C Methods. 2019;25(6):334-43. https://doi.org/ 10.1089/ten.TEC.2018.0318.

196. Goulart E, de Caires-Junior LC, Telles-Silva KA, et al. 3D bioprinting of liver spheroids derived from human induced pluripotent stem cells sustain liver function and viability in vitro. Biofabrication. 2019;12(1): 015010. https://doi.org/10.1088/1758$5090 / a b 4 a 30$.

197. Ostrovidov S, Salehi S, Costantini M, et al. 3D bioprinting in skeletal muscle tissue engineering. Small. 2019;15(24): e1805530. https://doi.org/10. 1002/smll.201805530.

198. Sorkio A, Koch L, Koivusalo L, et al. Human stem cell based corneal tissue mimicking structures using laser-assisted 3D bioprinting and functional bioinks. Biomaterials. 2018;171:57-71. https://doi. org/10.1016/j.biomaterials.2018.04.034.

199. Duarte Campos DF, Rohde M, Ross M, et al. Corneal bioprinting utilizing collagen-based bioinks and primary human keratocytes. J Biomed Mater Res A. 2019;107(9):1945-53. https://doi.org/10.1002/jbm. a.36702.

200. Lorber B, Hsiao WK, Hutchings IM, et al. Adult rat retinal ganglion cells and glia can be printed by piezoelectric inkjet printing. Biofabrication. 2014;6(1): 015001. https://doi.org/10.1088/1758$5082 / 6 / 1 / 015001$.

201. Masaeli E, Forster V, Picaud S, et al. Tissue engineering of retina through high resolution 3-dimensional inkjet bioprinting. Biofabrication. 2020;12(2): 025006. https://doi.org/10.1088/1758$5090 / \mathrm{ab} 4 \mathrm{a} 20$.

202. Bai J, Wang C. Organoids and microphysiological systems: new tools for ophthalmic drug discovery. Front Pharmacol. 2020;11:407. https://doi.org/10. 3389/fphar.2020.00407.

203. Dutta D, Heo I, Clevers H. Disease modeling in stem cell-derived 3D organoid systems. Trends Mol Med. 2017;23(5):393-410. https://doi.org/10.1016/j. molmed.2017.02.007.

204. Rae C, Amato F, Braconi C. Patient-derived organoids as a model for cancer drug discovery. Int J Mol Sci. 2021. https://doi.org/10.3390/ijms22073483.

205. Foster JW, Wahlin K, Adams SM, et al. Cornea organoids from human induced pluripotent stem cells. Sci Rep. 2017;7:41286. https://doi.org/10. $1038 /$ srep41286. 
206. Eiraku M, Takata N, Ishibashi H, et al. Self-organizing optic-cup morphogenesis in three-dimensional culture. Nature. 2011;472(7341):51-6. https://doi. org/10.1038/nature09941.

207. Nakano T, Ando S, Takata N, et al. Self-formation of optic cups and storable stratified neural retina from human ESCs. Cell Stem Cell. 2012;10(6):771-85. https://doi.org/10.1016/j.stem.2012.05.009.

208. Zhong X, Gutierrez C, Xue T, et al. Generation of three-dimensional retinal tissue with functional photoreceptors from human iPSCs. Nat Commun. 2014;5:4047. ncomms5047.

209. Jodat YA, Kang MG, Kiaee K, et al. Human-derived organ-on-a-chip for personalized drug development. Curr Pharm Des. 2018;24(45):5471-86. https://doi.org/10.2174/ 1381612825666190308150055.

210. Haderspeck JC, Chuchuy J, Kustermann S, et al. Organ-on-a-chip technologies that can transform ophthalmic drug discovery and disease modeling. Expert Opin Drug Discov. 2019;14(1):47-57. https://doi.org/10.1080/17460441.2019.1551873.

211. Seo J, Byun WY, Alisafaei F, et al. Multiscale reverse engineering of the human ocular surface. Nat Med. 2019;25(8):1310-8. https://doi.org/10.1038/ s41591-019-0531-2.

212. Chung M, Lee S, Lee BJ, et al. Wet-AMD on a chip: modeling outer blood-retinal barrier in vitro. Adv Healthc Mater. 2018. https://doi.org/10.1002/ adhm.201700028.

213. Achberger K, Probst C, Haderspeck J, et al. Merging organoid and organ-on-a-chip technology to generate complex multi-layer tissue models in a human retina-on-a-chip platform. Elife. 2019. https://doi. org/10.7554/eLife.46188.

214. Akbarzadeh A, Rezaei-Sadabady R, Davaran S, et al. Liposome: classification, preparation, and applications. Nanoscale Res Lett. 2013;8(1):102. https:// doi.org/10.1186/1556-276x-8-102.

215. Alavi M, Karimi N, Safaei M. Application of various types of liposomes in drug delivery systems. Adv Pharm Bull. 2017;7(1):3-9. https://doi.org/10. 15171/apb.2017.002.

216. Ag Seleci D, Seleci M, Walter J-G, et al. Niosomes as nanoparticular drug carriers: fundamentals and recent applications. J Nanomater. 2016;2016: 7372306. https://doi.org/10.1155/2016/7372306.

217. Ge X, Wei M, He S, et al. Advances of non-ionic surfactant vesicles (niosomes) and their application in drug delivery. Pharmaceutics. 2019. https://doi. org/10.3390/pharmaceutics11020055.

218. Trivedi R, Kompella UB. Nanomicellar formulations for sustained drug delivery: strategies and underlying principles. Nanomedicine. 2010;5(3):485-505. https://doi.org/10.2217/nnm.10.10.

219. Vijeth S, Heggannavar G, Kariduraganavar M. Encapsulating wall materials for micro-/nanocapsules. Microencapsulation - processes, technologies and industrial applications. 2018. https://doi.org/ 10.5772/intechopen.82014.

220. Hu SH, Chen SY, Gao X. Multifunctional nanocapsules for simultaneous encapsulation of hydrophilic and hydrophobic compounds and on-demand release. ACS Nano. 2012;6(3):2558-65. https://doi. org/10.1021/nn205023w.

221. Wohlfart S, Gelperina S, Kreuter J. Transport of drugs across the blood-brain barrier by nanoparticles. J Control Release. 2012;161(2):264-73. https:// doi.org/10.1016/j.jconrel.2011.08.017.

222. Lancina MG 3rd, Yang H. Dendrimers for ocular drug delivery. Can J Chem. 2017;95(9):897-902. https://doi.org/10.1139/cjc-2017-0193.

223. Kenyon KR, Qiao L, Lee E. Hydrogel liquid ocular bandage (OcuSeal $\left.{ }^{\circledR}\right)$ is an effective microbial barrier. Investig Ophthalmol Vis Sci. 2014;55(13): 2547-2547.

224. Obiedallah MM, Abdel-Mageed AM, Elfaham TH. Ocular administration of acetazolamide microsponges in situ gel formulations. Saudi Pharm J. 2018;26(7):909-20. https://doi.org/10.1016/j.jsps. 2018.01.005.

225. Wei Y, Li C, Zhu Q, et al. Comparison of thermosensitive in situ gels and drug-resin complex for ocular drug delivery: in vitro drug release and in vivo tissue distribution. Int J Pharm. 2020;578: 119184. https://doi.org/10.1016/j.ijpharm.2020. 119184.

226. Shi H, Wang Y, Bao Z, et al. Thermosensitive glycol chitosan-based hydrogel as a topical ocular drug delivery system for enhanced ocular bioavailability. Int J Pharm. 2019;570: 118688. https://doi.org/10. 1016/j.ijpharm.2019.118688.

227. Kouchak M, Mahmoodzadeh M, Farrahi F. Designing of a pH-triggered Carbopol®/HPMC in situ gel for ocular delivery of dorzolamide $\mathrm{HCl}$ : in vitro, in vivo, and ex vivo evaluation. AAPS PharmSciTech. 2019;20(5):210. https://doi.org/10.1208/ s12249-019-1431-y.

228. Jain P, Jaiswal CP, Mirza MA, et al. Preparation of levofloxacin loaded in situ gel for sustained ocular 
delivery: in vitro and ex vivo evaluations. Drug Dev Ind Pharm. 2020;46(1):50-6. https://doi.org/10. 1080/03639045.2019.1698598.

229. Noreen S, Ghumman SA, Batool F, et al. Terminalia arjuna gum/alginate in situ gel system with prolonged retention time for ophthalmic drug delivery. Int J Biol Macromol. 2020;152:1056-67. https://doi. org/10.1016/j.ijbiomac.2019.10.193.

230. Shelley H, Rodriguez-Galarza RM, Duran SH, et al. In situ gel formulation for enhanced ocular delivery of nepafenac. J Pharm Sci. 2018;107(12):3089-97. https://doi.org/10.1016/j.xphs.2018.08.013.

231. Destruel PL, Zeng N, Brignole-Baudouin F, et al. In situ gelling ophthalmic drug delivery system for the optimization of diagnostic and preoperative mydriasis: in vitro drug release, cytotoxicity and mydriasis pharmacodynamics. Pharmaceutics. 2020. pharmaceutics12040360.

232. Bhalerao H, Koteshwara KB, Chandran S. Brinzolamide dimethyl sulfoxide in situ gelling ophthalmic solution: formulation optimisation and in vitro and in vivo evaluation. AAPS PharmSciTech. 2020;21(2):69. https://doi.org/10.1208/ s12249-019-1555-0.

233. Henriksson JT, McDermott AM, Bergmanson JP. Dimensions and morphology of the cornea in three strains of mice. Investig Ophthalmol Vis Sci. 2009;50(8):3648-54. https://doi.org/10.1167/iovs. 08-2941.

234. Yin J, Huang J, Chen C, et al. Corneal complications in streptozocin-induced type I diabetic rats. Investig Ophthalmol Vis Sci. 2011;52(9):6589-96. https:// doi.org/10.1167/iovs.11-7709.

235. Bozkir G, Bozkir M, Dogan H, et al. Measurements of axial length and radius of corneal curvature in the rabbit eye. Acta Med Okayama. 1997;51(1): 9-11. https://doi.org/10.18926/amo/30804.

236. Augusteyn RC, Maceo Heilman B, Ho A, et al. Nonhuman primate ocular biometry. Investig Ophthalmol Vis Sci. 2016;57(1):105-14. https://doi. org/10.1167/iovs.15-18169.

237. Augusteyn RC, Nankivil D, Mohamed A, et al. Human ocular biometry. Exp Eye Res. 2012;102: 70-5. https://doi.org/10.1016/j.exer.2012.06.009.

238. Schulz D, Iliev ME, Frueh BE, et al. In vivo pachymetry in normal eyes of rats, mice and rabbits with the optical low coherence reflectometer. Vis Res. 2003;43(6):723-8. https://doi.org/10.1016/s00426989(03)00005-1.
239. Zhao M, Hejkal JJ, Camras CB, et al. Aqueous humor dynamics during the day and night in juvenile and adult rabbits. Investig Ophthalmol Vis Sci. 2010;51(6):3145-51. https://doi.org/10.1167/iovs. $09-4415$.

240. Toris CB, Risma JM, Gonzales-Martinez J, et al. Aqueous humor dynamics in inbred rhesus monkeys with naturally occurring ocular hypertension. Exp Eye Res. 2010;91(6):860-5. https://doi.org/10. 1016/j.exer.2010.09.011.

241. Sadoughi MM, Einollahi B, Einollahi N, et al. Measurement of central corneal thickness using ultrasound pachymetry and orbscan II in normal eyes. J Ophthalmic Vis Res. 2015;10(1):4-9. https://doi. org/10.4103/2008-322x.156084.

242. Zhou X, Xie J, Shen M, et al. Biometric measurement of the mouse eye using optical coherence tomography with focal plane advancement. Vis Res. 2008;48(9):1137-43. https://doi.org/10.1016/j. visres.2008.01.030.

243. Massof RW, Chang FW. A revision of the rat schematic eye. Vis Res. 1972;12(5):793-6. https://doi. org/10.1016/0042-6989(72)90005-3.

244. Hughes A. A schematic eye for the rabbit. Vis Res. 1972;12(1):123-38. https://doi.org/10.1016/00426989(72)90143-5.

245. Fernandes A, Bradley DV, Tigges M, et al. Ocular measurements throughout the adult life span of rhesus monkeys. Investig Ophthalmol Vis Sci. 2003;44(6):2373-80. https://doi.org/10.1167/iovs. $02-0944$.

246. Deering MF. A photon accurate model of the human eye. ACM Trans Graph. 2005;24:649-58.

247. Clough JD, Parikh CH, Edelhauser HF. Anterior chamber, lens and globe volumes in Balb/C and C57/BL6 mice. Investig Ophthalmol Vis Sci. 2003;44:648.

248. Mermoud A, Baerveldt G, Minckler DS, et al. Aqueous humor dynamics in rats. Graefes Arch Clin Exp Ophthalmol. 1996;234(Suppl 1):S198-203. https:// doi.org/10.1007/bf02343072.

249. Pederson JE, Gaasterland DE, MacLellan HM. Anterior chamber volume determination in the rhesus monkey. Investig Ophthalmol Vis Sci. 1978;17(8): 784-7.

250. Wang D, Qi M, He M, et al. Ethnic difference of the anterior chamber area and volume and its association with angle width. Investig Ophthalmol Vis Sci. 2012;53(6):3139-44. https://doi.org/10.1167/iovs. $12-9776$. 
251. Aihara M, Lindsey JD, Weinreb RN. Aqueous humor dynamics in mice. Investig Ophthalmol Vis Sci. 2003;44(12):5168-73. https://doi.org/10.1167/iovs. 03-0504.

252. Conrad JM, Robinson JR. Aqueous chamber drug distribution volume measurement in rabbits. J Pharm Sci. 1977;66(2):219-24. https://doi.org/10. 1002/jps.2600660222.

253. Kaplan HJ, Chiang CW, Chen J, Song SK. Vitreous volume of the mouse measured by quantitative high-resolution MRI. Investig Ophthalmol Vis Sci. 2010;51:4414.

254. Dureau P, Bonnel S, Menasche M, et al. Quantitative analysis of intravitreal injections in the rat. Curr Eye Res. 2001;22(1):74-7. https://doi.org/10.1076/ceyr. 22.1.74.6974.

255. Kane A, Barza M, Baum J. Intravitreal injection of gentamicin in rabbits. Effect of inflammation and pigmentation on half-life and ocular distribution. Investig Ophthalmol Vis Sci. 1981;20(5):593-7.

256. Barza M, Kane A, Baum J. Pharmacokinetics of intravitreal carbenicillin, cefazolin, and gentamicin in rhesus monkeys. Investig Ophthalmol Vis Sci. 1983;24(12):1602-6.

257. Johnson MW. Posterior vitreous detachment: evolution and complications of its early stages. Am J Ophthalmol. 2010;149(3):371-382.e371. https:// doi.org/10.1016/j.ajo.2009.11.022.

258. Ferguson LR, Dominguez JM 2nd, Balaiya S, et al. Retinal thickness normative data in wild-type mice using customized miniature SD-OCT. PLoS ONE. 2013;8(6): e67265. https://doi.org/10.1371/journal. pone. 0067265 .

259. Carpenter CL, Kim AY, Kashani AH. Normative retinal thicknesses in common animal models of eye disease using spectral domain optical coherence tomography. Adv Exp Med Biol. 2018;1074:157-66. https://doi.org/10.1007/978-3-319-75402-4_20.
260. Chen J, Luo Q, Huang C, et al. Morphology of inner retina in rhesus monkeys of various ages: a comparative study. J Ophthalmol. 2019;2019:7089342. https://doi.org/10.1155/2019/7089342.

261. Jo YJ, Heo DW, Shin YI, et al. Diurnal variation of retina thickness measured with time domain and spectral domain optical coherence tomography in healthy subjects. Investig Ophthalmol Vis Sci. 2011;52(9):6497-500. https://doi.org/10.1167/iovs. 11-7403.

262. Weir AB, Collins M. Assessing ocular toxicology in laboratory animals. New York: Springer; 2012.

263. Chrai SS, Patton TF, Mehta A, et al. Lacrimal and instilled fluid dynamics in rabbit eyes. J Pharm Sci. 1973;62(7):1112-21. https://doi.org/10.1002/jps. 2600620712 .

264. Holly FK, LauKaitis SJ, Esquivel ED. Kinetics of lacrimal secretions in normal human subject. Curr Eye Res. 1984;3(7):897-910. https://doi.org/10. 3109/02713688409167207.

265. Mishima S, Gasset A, Klyce SD Jr, et al. Determination of tear volume and tear flow. Investig Ophthalmol Vis Sci. 1966;5(3):264-76.

266. McClellan AJ, Volpe EA, Zhang X, et al. Ocular surface disease and dacryoadenitis in aging C57BL/6 mice. Am J Pathol. 2014;184(3):631-43. https://doi. org/10.1016/j.ajpath.2013.11.019.

267. Sullivan DA, Allansmith MR. Hormonal modulation of tear volume in the rat. Exp Eye Res. 1986;42(2): $131-9$. https://doi.org/10.1016/00144835(86)90037-0.

268. Yoon KC, De Paiva CS, Qi H, et al. Desiccating environmental stress exacerbates autoimmune lacrimal keratoconjunctivitis in non-obese diabetic mice. J Autoimmun. 2008;30(4):212-21. https:// doi.org/10.1016/j.jaut.2007.09.003. 